\title{
Model of Mind Mapping to Compilation of Audit Report
}

\author{
Alireza Leissi \\ PhD Candidate of Azad University of Marand Unit, Marnd, Iran \\ (alirezaleissi@gmail.com)) \\ Aliakbar Nonahal nahr * \\ Assistant Professor, Accounting Department, Bostanabad Azad University, \\ Bostanabad,Iran(Corresponding Author).anonahal@gmail.com \\ Heydar Mohammadzadeh Salteh \\ Associate Professor; Azad University of Marand Unit, Marnd, Iran \\ (salteh2008@gmail.com) \\ Mahdi Zeynali \\ Assistant Professor, Accounting Department, Tabriz Azad University, \\ Tabriz,Iran (dr.zeynali@gmail.com)
}

\begin{abstract}
:
Auditing is a judgmental process that requires the professional judgments of auditors in both the performance and reporting stages. Psychological theories (dual code theory and load theory) state that visual information can make better judgments and decisions than its linear functions (states) by stimulating the nonlinear functions of the human brain. Thus, in the present study, the mental mapping model based on the above-mentioned psychological theories has been analyze to compile the audit report using statistical tests such as binomial test, t-test, Kolmogorov test and Friedman test. In order to design a mind mapping model, 53 independent auditors and academic experts were surveyed in 2020 to first extract data related to the main factors influencing reporting and then to use it to develop and design a mind mapping model. The model of mind map extracted and compiled in the present study can be use as an effective tool in compiling the auditor's report as a desirable and reliable adjustment of the audit report.
\end{abstract}

Keywords: Professional Judgment, Cognitive load theory, Dual-Coding theory, Mind Mapping, Linear and Nonlinear Brain Functions, Nonlinear Judgments.

Copyrights:

This license only allowing others to download your works and share them with others as long as they credit you, but they can't change them in any way or use them commercial. 


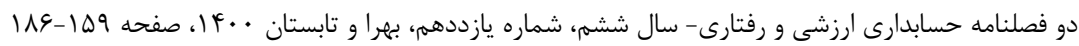

\section{ارائه التَّى نقشهير دازى ذهنى در بهبود تزارش ترى حسابرسى

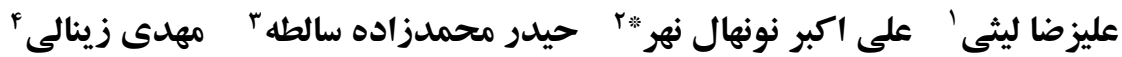

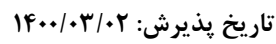 \\ تاريخ دريافت:•}

جكيده

حسابرسى فرآيندى قضاوتى است كه هم در مرحله اجراى آزمونها و هم كزارش قرىى آن

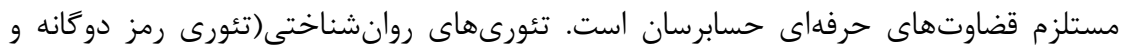
تئورى بارشناختى) بيان مى كنند كه اطلاعات تصويرى مىتواند از طريق تحريك عملكردهاى

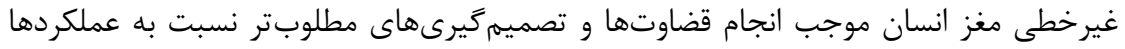

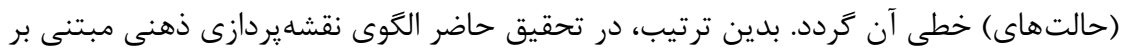

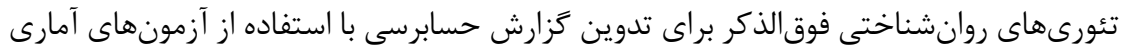

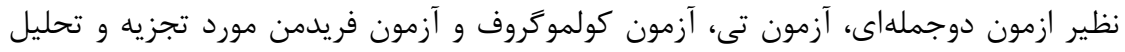

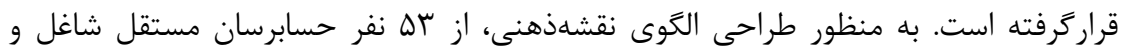

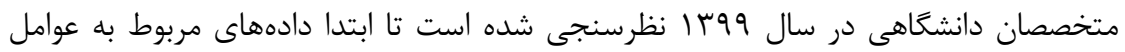

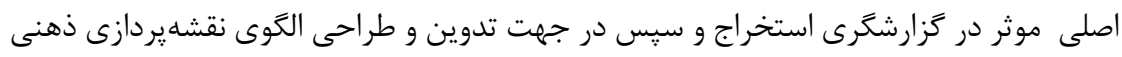

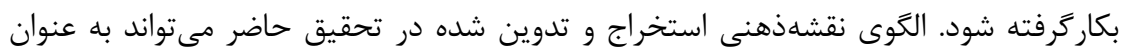

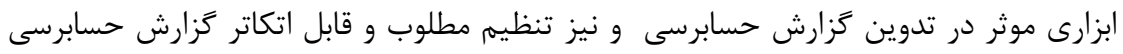
بكار كرفته شود. وازه هاى كليدى: قضاوت حرفهاى، عملكردهاى خطى و ونئ غير خطى مغز، نظريه بارشناختى، نظريه

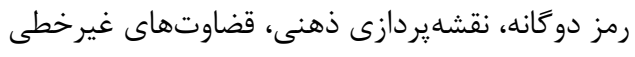

\footnotetext{
' ' دانشجوى دكترى حسابدارى، دانشكده علوم انسانى، واحد مرند، دانشكاه آزاد اسلامى مرند، ايران alirezaleissi@gmail.com × استاديار كروه حسابدارى، واحد بستان آباد، دانشگاه آزاد اسلامى، بستان آباد، ايران (نويسنده مسئول) anonahal@gmail.com ״ دانشيار كروه حسابدارى،دانشكده علوم انسانى، واحد مرند، دانشخاه آزاد اسلامى، مرند، ايران salteh2008@gmail.com " استاديار كروه حسابدارى، دانشكده اقتصاد مديريت حسابدارى، واحد تبريز، دانشكاه آزاد اسلامى،

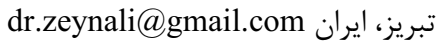


حسابرسى، حرفهاى است كه شباهت زيادى به قضاوت در دادگاهها دارد. هم قاضى و هم

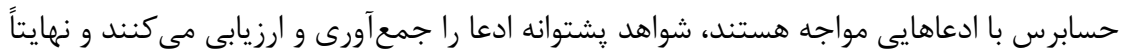
براساس معيارهايى كه در اختيار آنها قرارداده شده در قالب زَارش حسابرسى، قضاوت و نظر

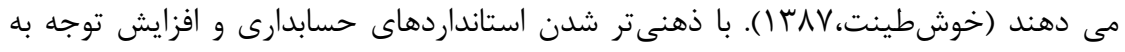
اندازه گيرىهاى مبتنى بر ارزش منصفانه، افراد حرفهاى نيازمند بكارگيرى بيشتر و بهتر قضاوت

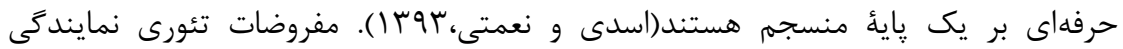
ترديدهايى را ييرامون كيفيت اطلاعات حسابدارى شركتها ايجاد مى كند: مبنى بر اينكه تهييه كنندكان اطلاعات(مديران) بطور بالقوه به دنبال حداكثر نمودن منافع شخصى خود هستند و اين امر مى تواند متناقض با اهداف شركت و استفاده كنند مكانيزمى مستقل و مورد تائيد طرفين گزارشها، ايجاد شده است و هدف و وظيفه آن اظهارنظر درباره كيفيت و منصفانه بودن در قالب گزارش حسابرسى مى باشد كه به عنوان ابزار ارتباطى مئى

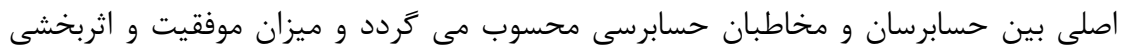
كزارش حسابرسى مى تواند اثربخشى فر آيند حسابرسى را رقانم بزند.

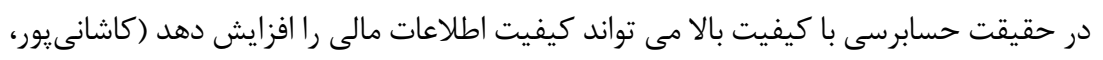

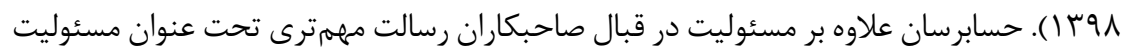
اجتماعى دارند، كه باعث مى شود كيفيت قضاوت حرفهاى (يعنى ستون حسابرسى) نقش با

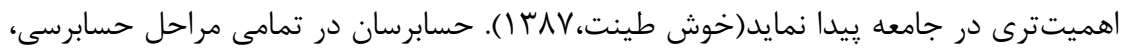
شامل اجراى آزمونهاى حسابرسى و تدوين ززارش حسابرسى از قضاوتهاى حرفهاى خود استفاده مى كنند و اين امر جالشهايى را براى حرفه حسابرسى ايجاد نموده است. قضاوت حرفهاى در حرفه حسابرسى و فرآيند آن موضوعى ييجيده است و از عوامل متعددى تاثير مى إنى يذيرد. در حقيقت در نظر گرفتن همه عوامل در بررسى كيفيت قضاوت ضرورى مى باشد(حسينى

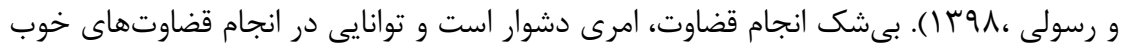
سنگبناى حرفه حسابرسى است و استانداردهاى حرفهاى بدون اعمال قضاوتحرفهاى هرگز

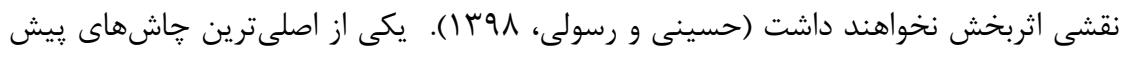
روى حرفه حسابرسى تاثير عوامل شناختى بر قضاوت حسابرسان (ويزگىهاى فردى) شامل

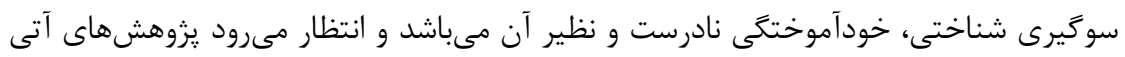
حسابرسى در حوزههاى شناختى بر روى افق قضاوت و ابزار آن متمركز گردد (ماليس و و 
انجام قضاوتهاى حرفهاى مبتنى بر توانمندىهاى ذهنى و خِكونكى بهرهبردارى از اين

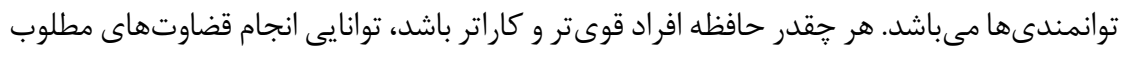

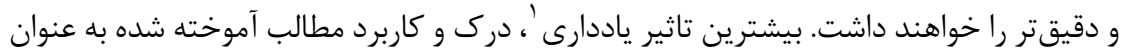

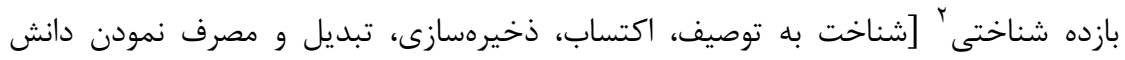

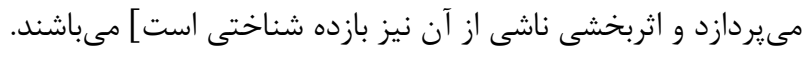

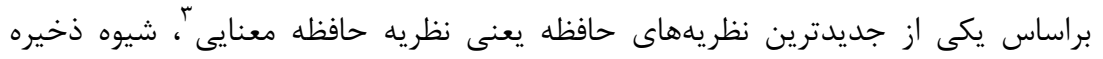

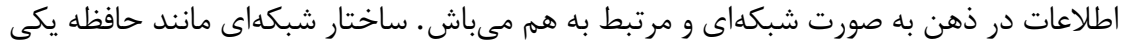

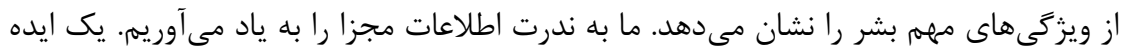

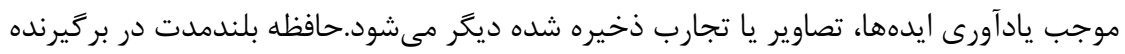

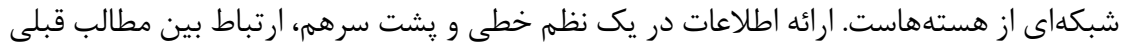

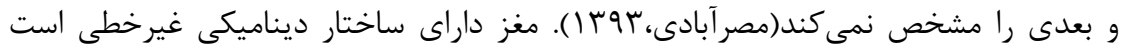

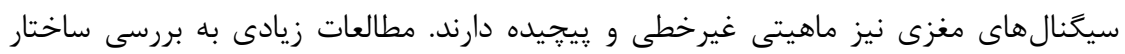

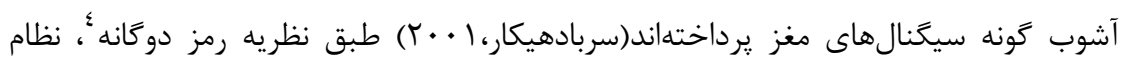

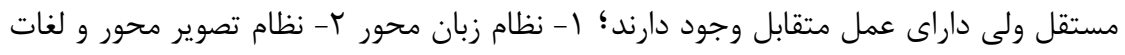

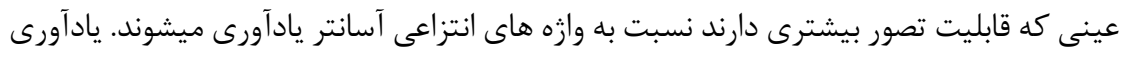

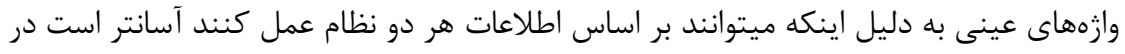

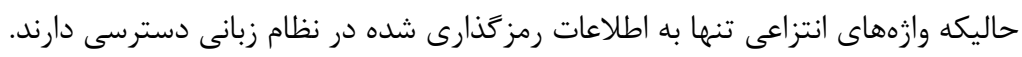

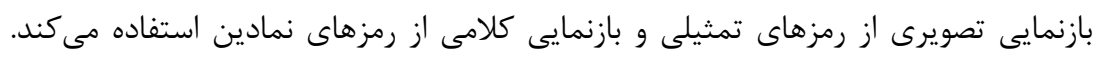

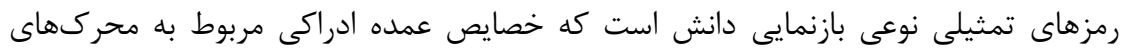

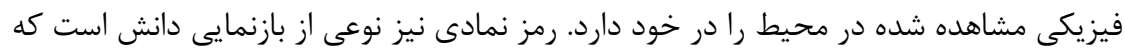

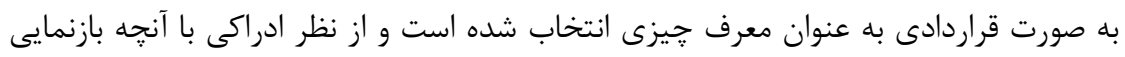

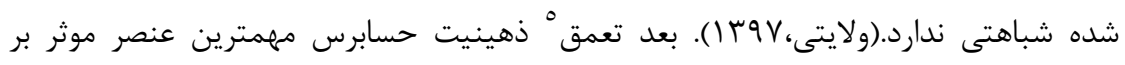

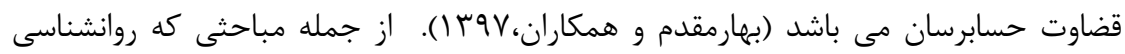

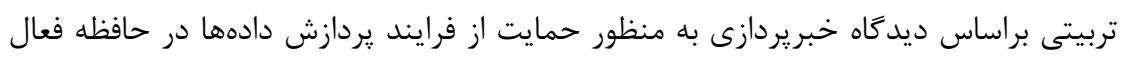

1 . Remembrance

2 . Cognitive efficiency

3. Semantic memory

4. Dual-Coding theory

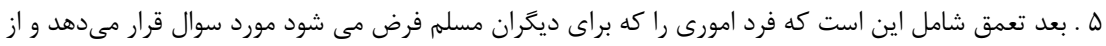

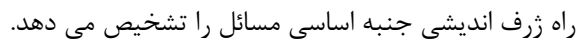


انسان ايجاد شده است نظريه بار شناختى' مى باشد. نظريه بارشناختى، حافظه كوتاه مدت محدود

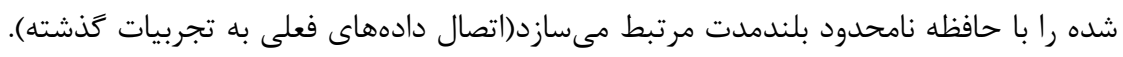

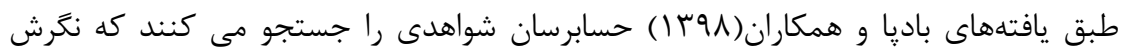

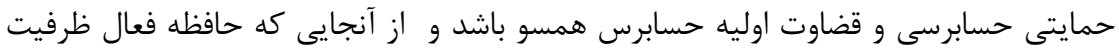

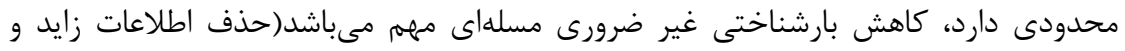

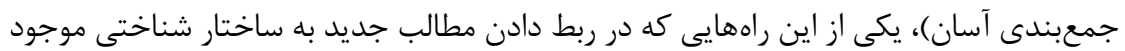

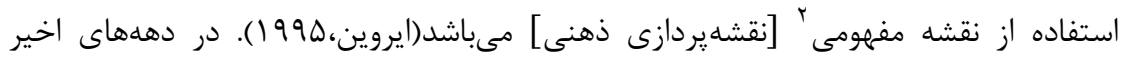

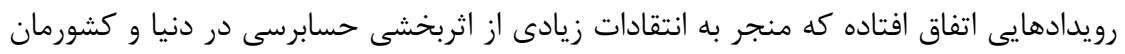

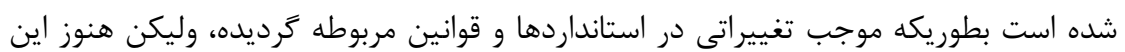

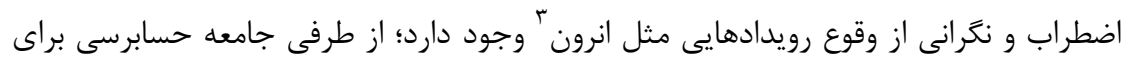

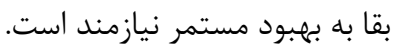

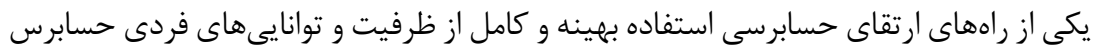

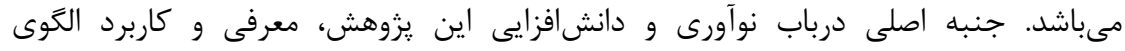

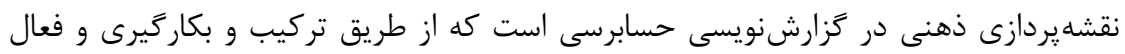

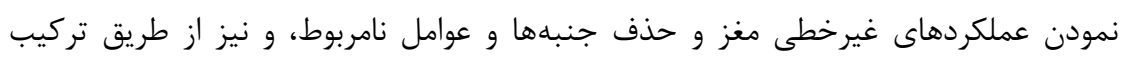

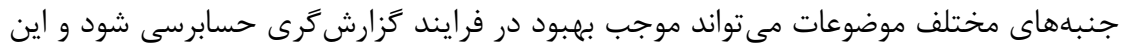

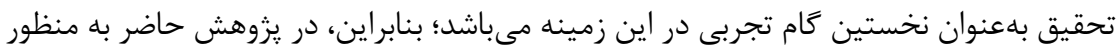

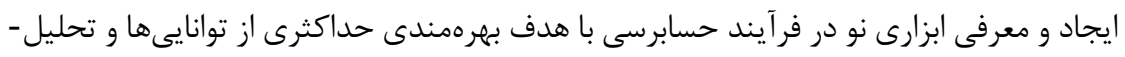

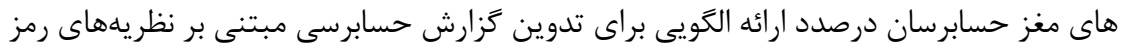

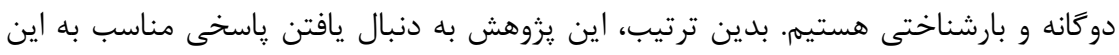

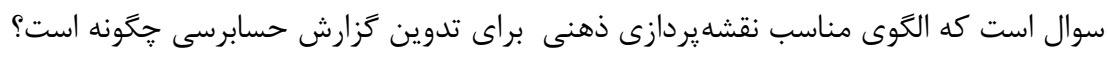

r-مبانى نظرى و بيشينه يخوهش

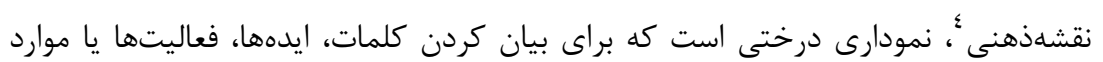

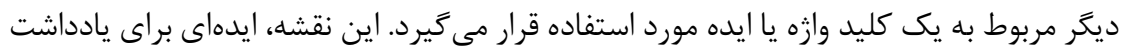

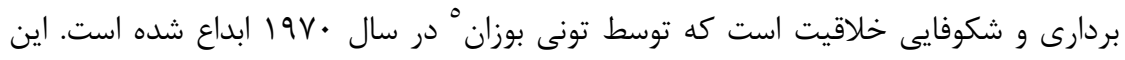

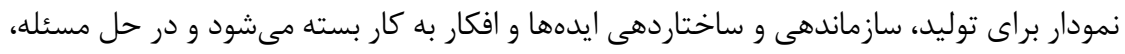

1 . Educational psychology

2 . Concept map

3. Enron

4. Mind map

5. Tony Buzan 
فرايند تصميم گيرى و نوشتن مىتواند مورد استفاده قرار بكيرد. عناصر يك نقشهذهنى به صورت

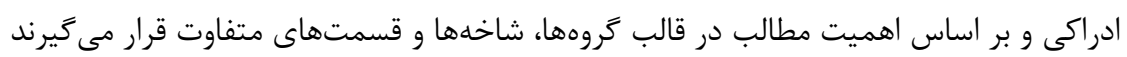

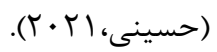

نقشههاى ذهنى را مىتوان براى مرور حافظه نيز به كار بست. ترسيم نقشهذهنى راهى ساده،

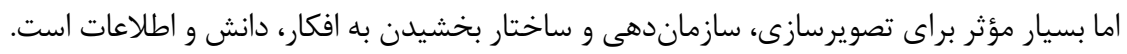

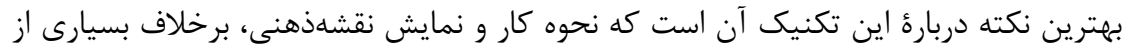

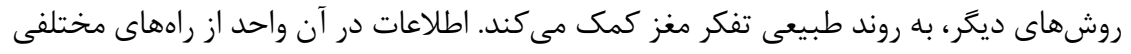

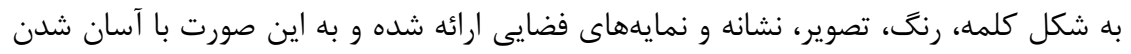

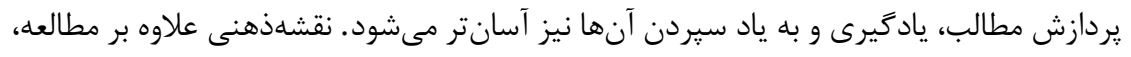

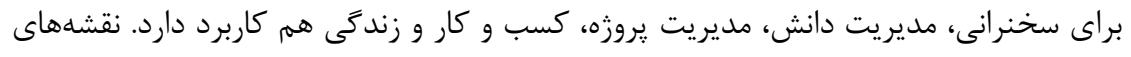

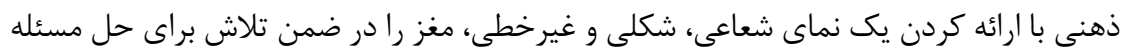

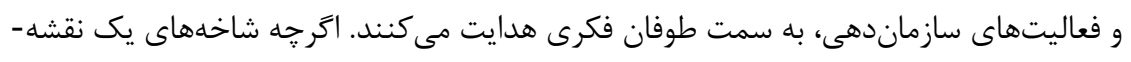

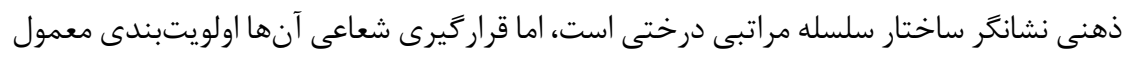

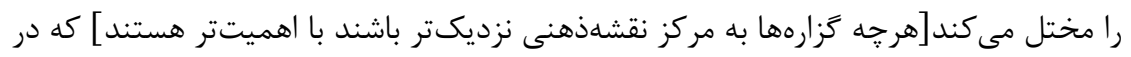

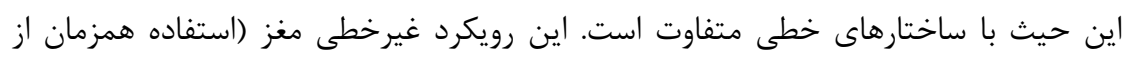

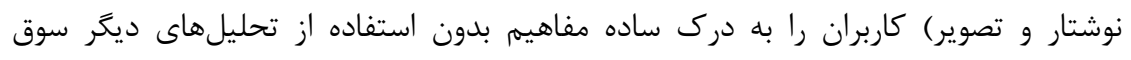

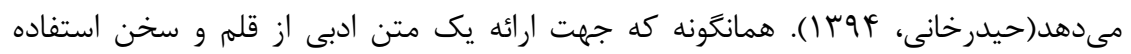

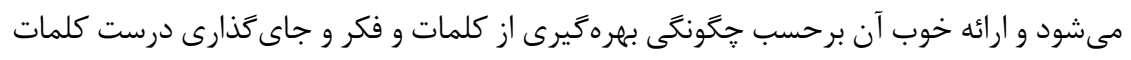

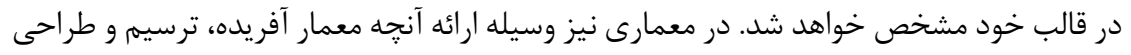

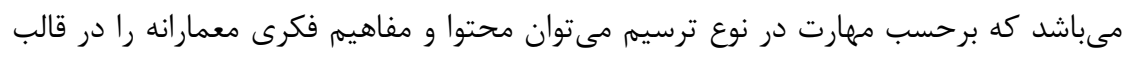

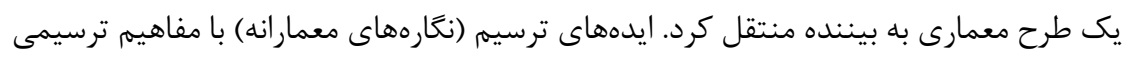

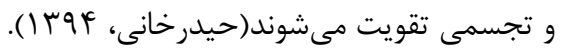

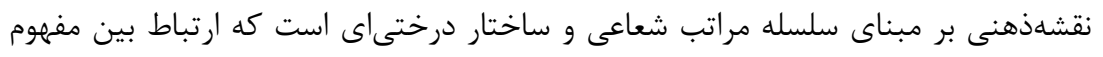

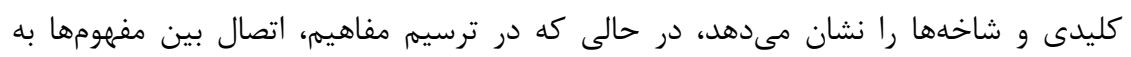

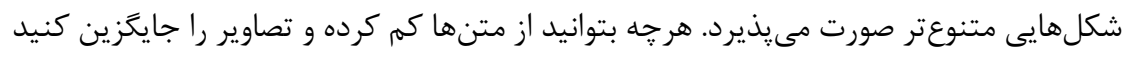

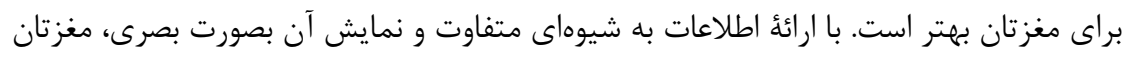

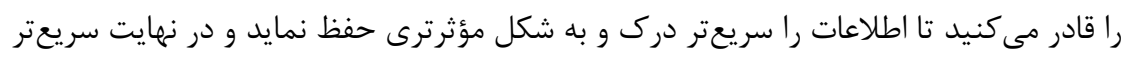




$$
\begin{aligned}
& \text { به ياد آورد. براى ترسيم نقشهذهنى نرمافزارهاى مختلفى 'در دسترس مىباشد (حسينى، ال • ؟). } \\
& \text { نمونهاى از نقشهذهنى در شكل ( (1) با موضوع دستور يك جلى جلسه ارائه شده است. }
\end{aligned}
$$

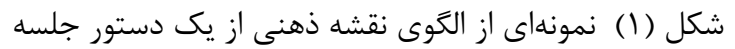

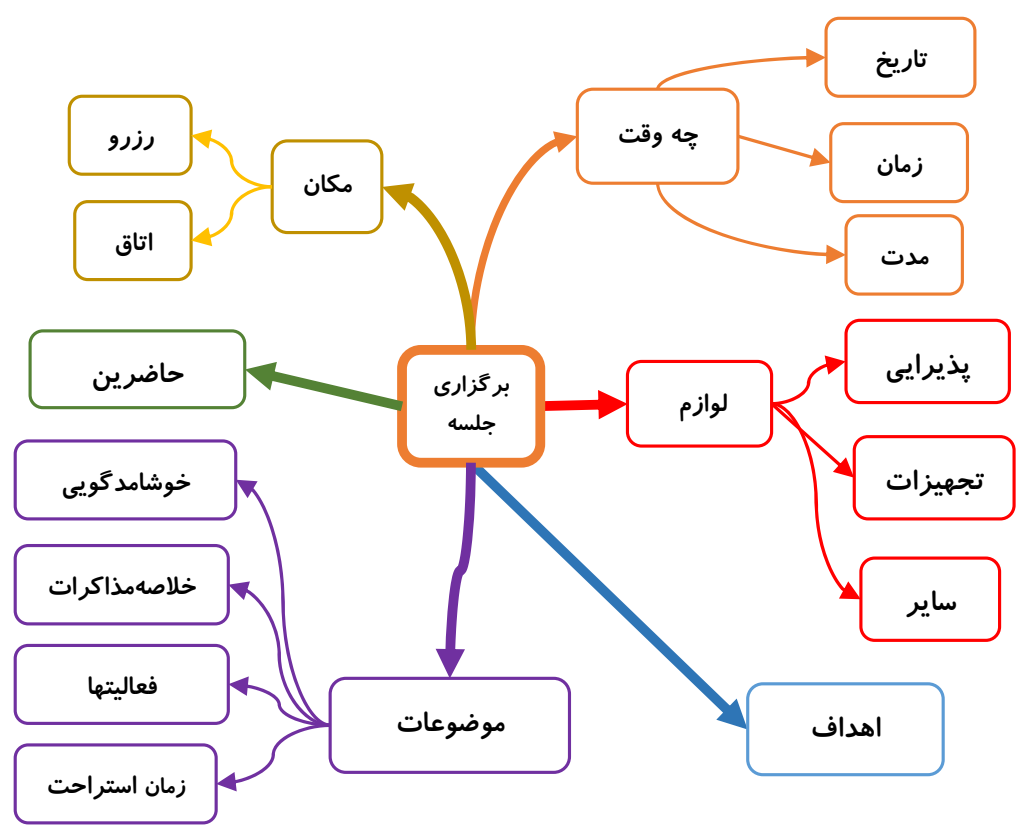

در يزوهش حاضر با استفاده از ابزار نقشه ذهنى، درصد تنظيم الكوى مناسب براى تدوين

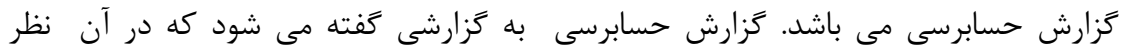

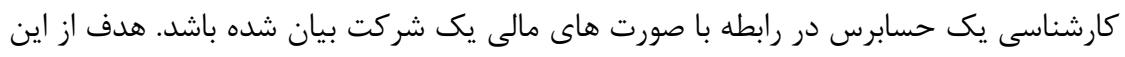

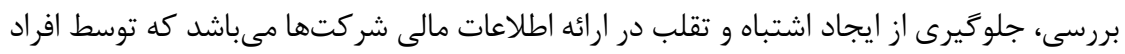
خبره صورت مى گيرد. نتيجه اين حسابرسى براى سهامداران و هيئت مديره، بانكها جهت ارائه وام و اعتبارات از اهميت ويزٔاى برخوردار است. به عبارت ديخر هدف زَزارش حسابرسى عبارت

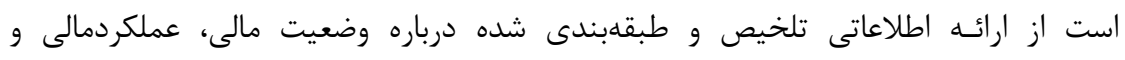
انعطافيذيرى مالى واحد تجارى است كه براى طيفى گسترده از استفاده كنندَّان صورتهاى

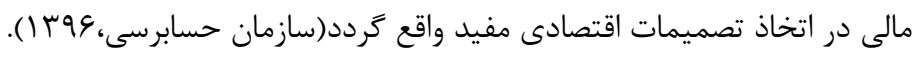

1. Office Visio, Concept draw, mind manager, inspiration, mindgenius, iMindMap, Xmind mindmup 


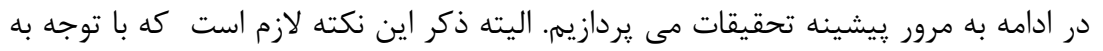

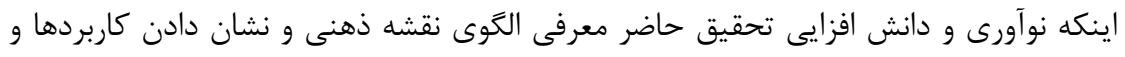

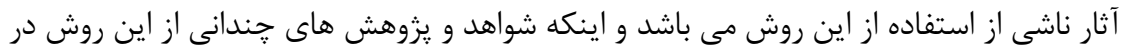

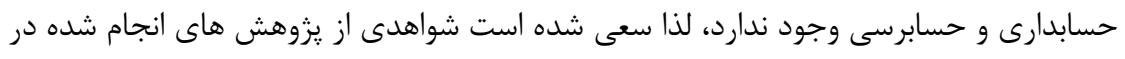

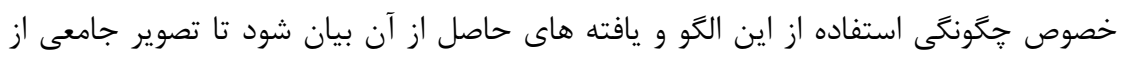
جايكاه اين الكو فراهم كردد.

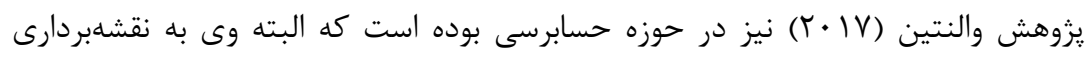

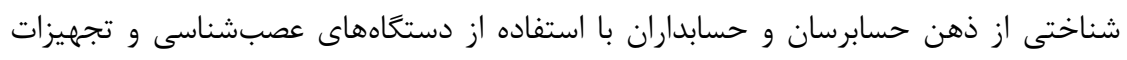

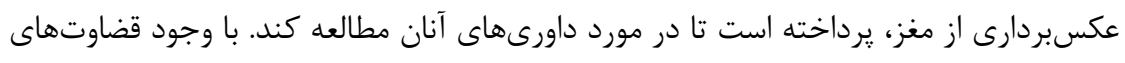

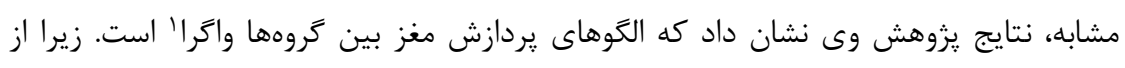

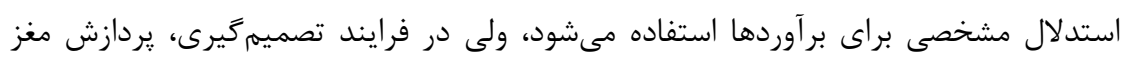
حسابرسان در حالتى يكدست بوده است.

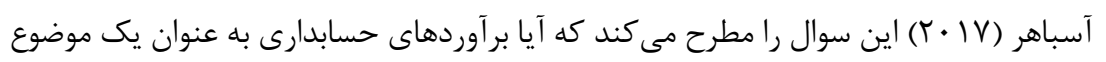

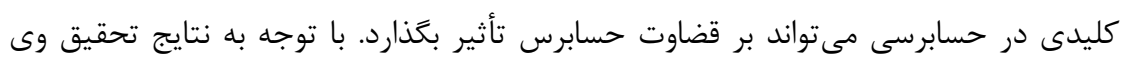

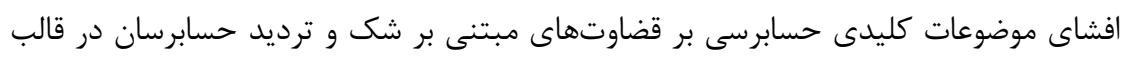

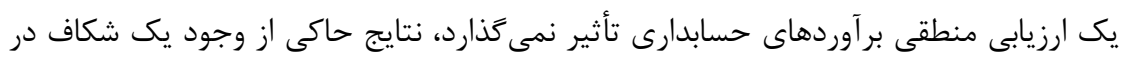

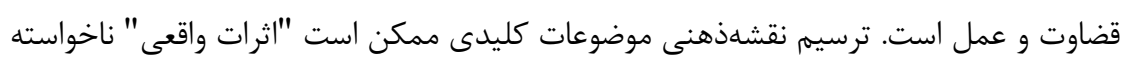

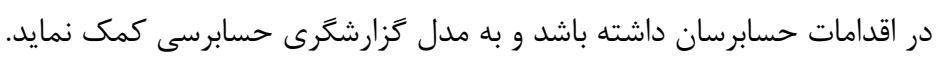

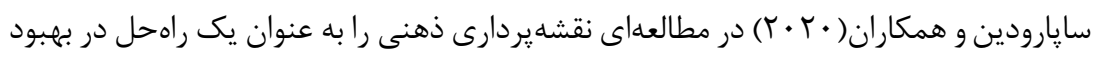

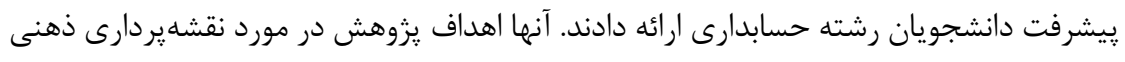

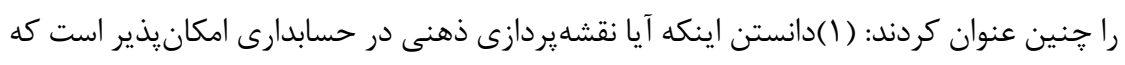

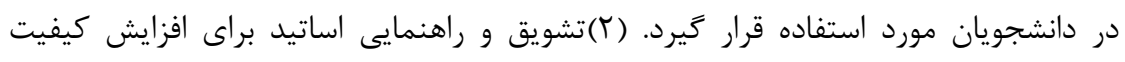

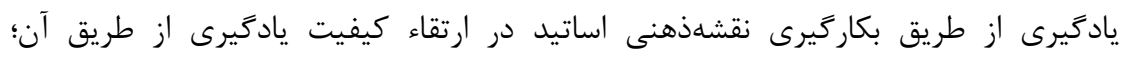

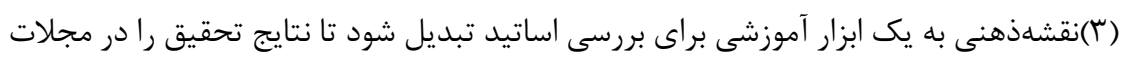

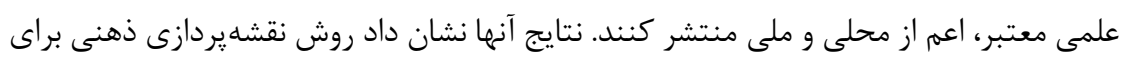

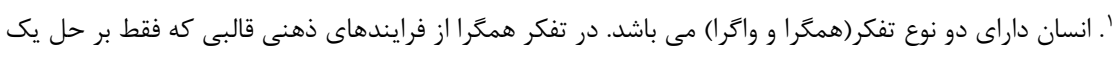

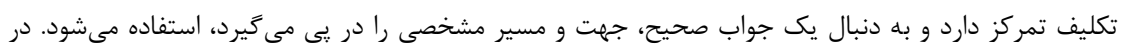

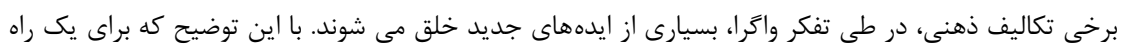

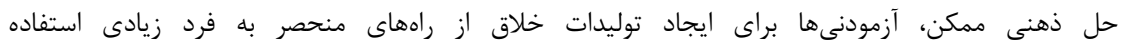


دانشجويان در حسابدارى مناسب بوده و باعث بهبود كيفيت يادگيرى مىشود. تحقيق گوساك و

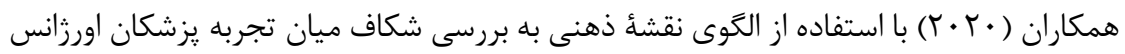

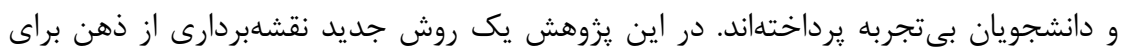

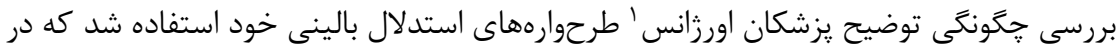

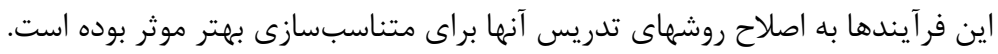

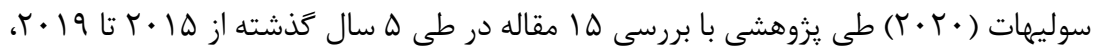
به مطالعه تحقيقات نقشهذهنى در ارتباط با مدلسازى مالى و تجزيه و تحليل آنها برداخت، وى إنى

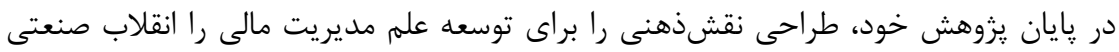

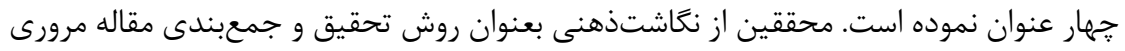
بهره جسته اند.

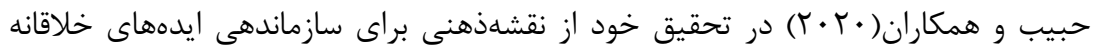

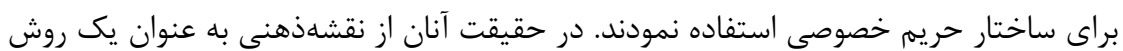

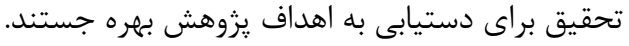

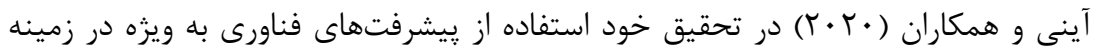

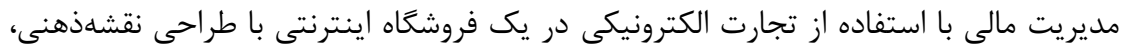

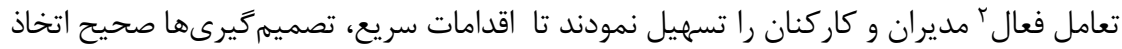

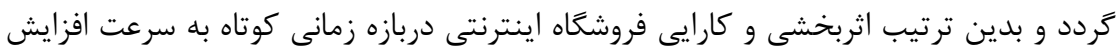

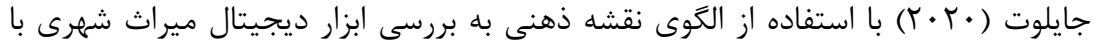

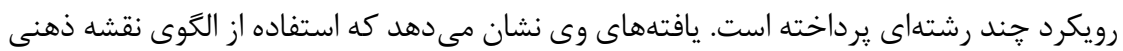

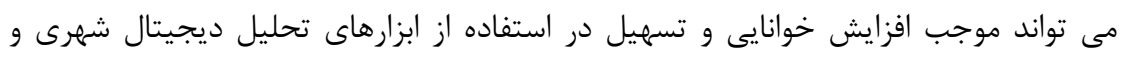

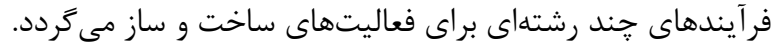

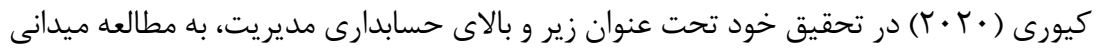

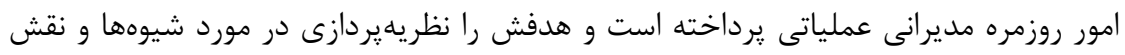

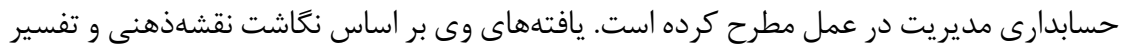
نقشههاى ذهنى ترسيم شده ارائه شده بود.

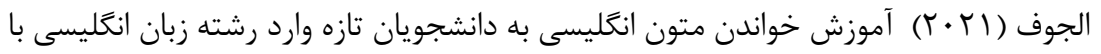

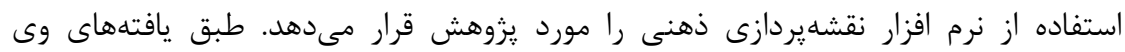

1 . Emergency physicians

2 . Active interaction 
دانشجويان تازه وارد، انغليسى را به عنوان زبان خارجى مى آموزند كه در درك متون انحليسى از

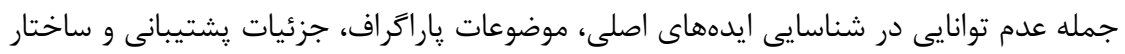

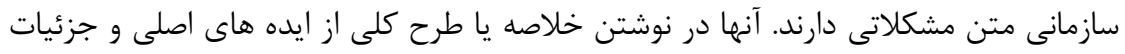

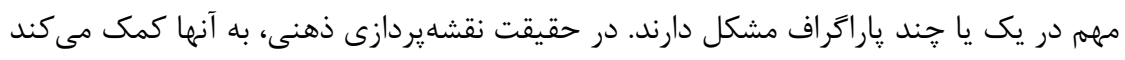

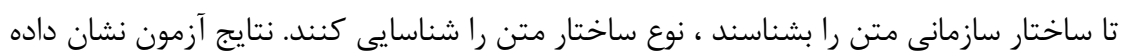

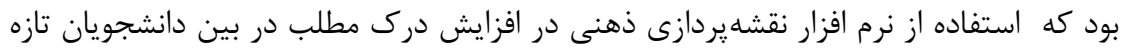

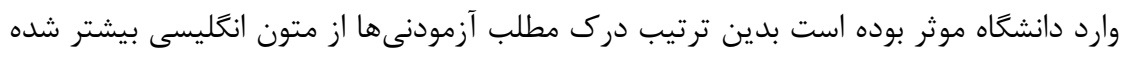

يزوهشهاى داخلى نسبتاً زيادى در خصوص نقشهيردازى ذهنى در كشورمان انجام شده است

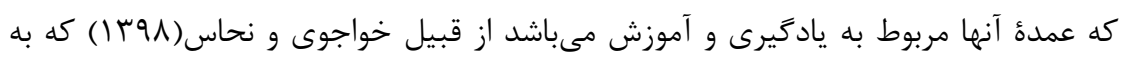

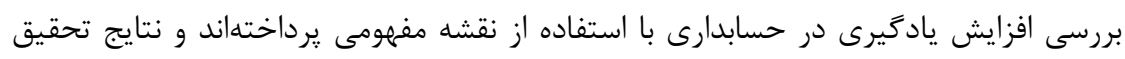

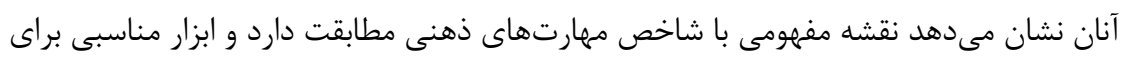

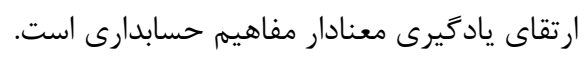

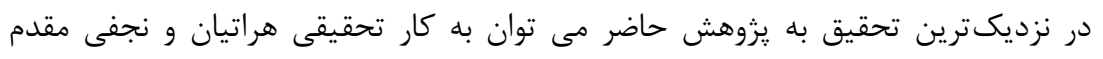

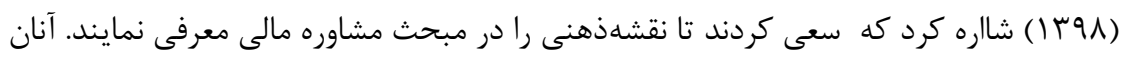

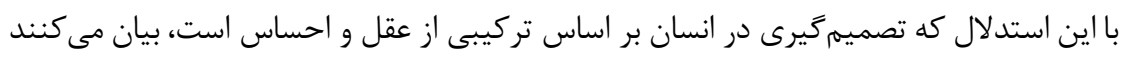

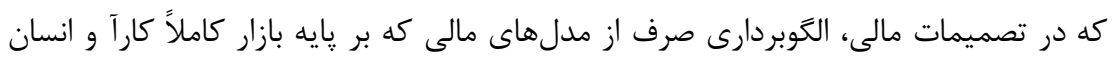

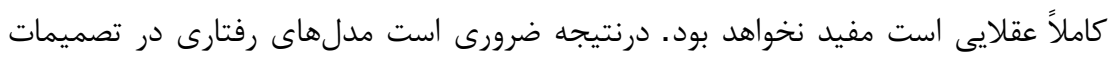

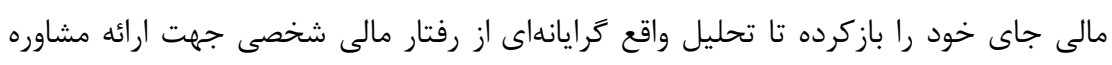

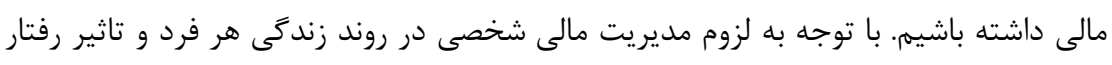

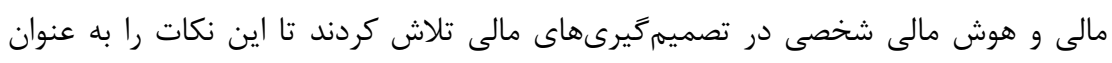

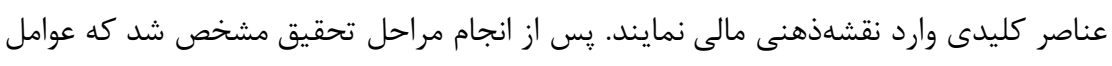

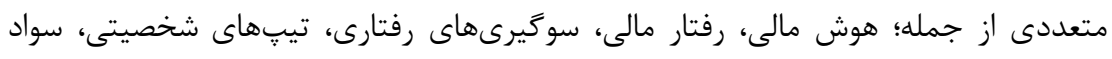

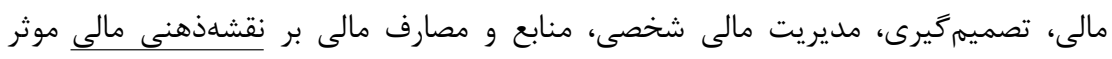

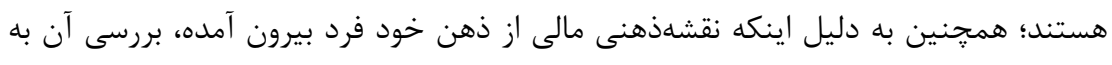

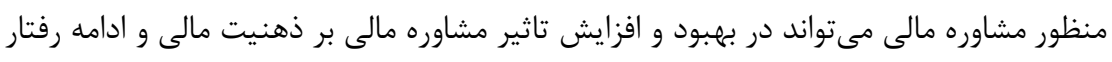
عملى مالى شخص متقاضى مشاوره بسيار مفيد واقع شود.

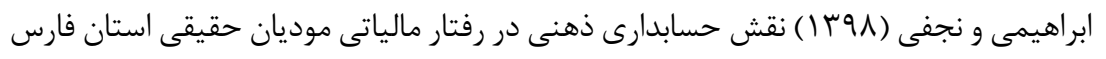

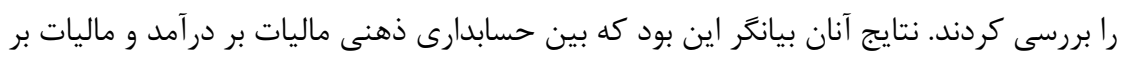

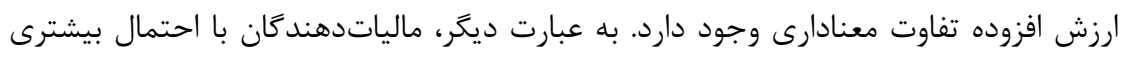


براى ماليات برارزش افزوده، نسبت به ماليات بر درآمد، حساب ذهنى جداگانهاى در نظر مى گيرند.

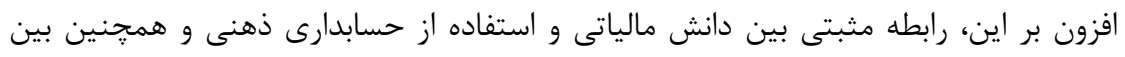
حسابدارى ذهنى و تمكين مالياتى وجود دارد.

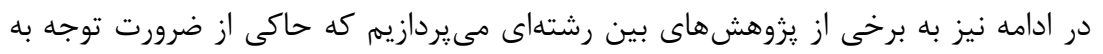

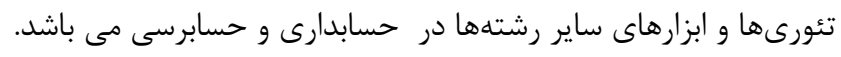

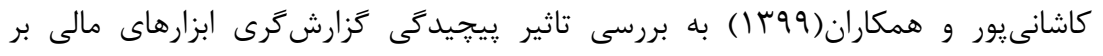

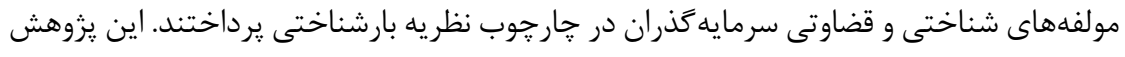

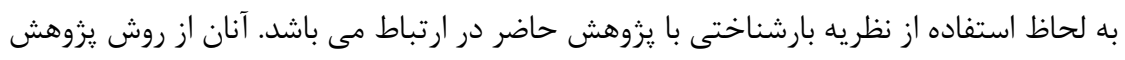

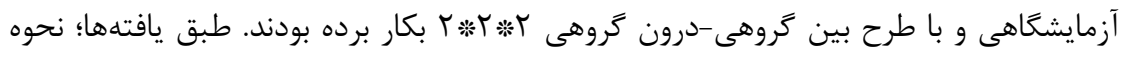

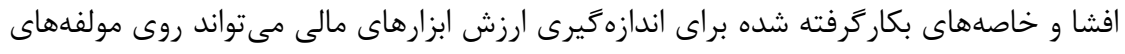

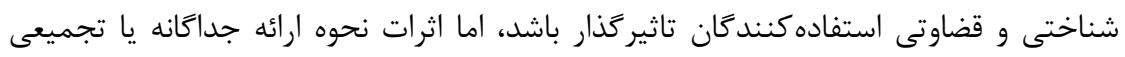

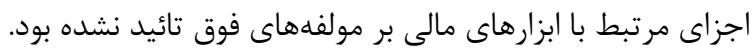

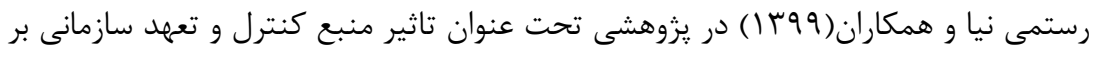

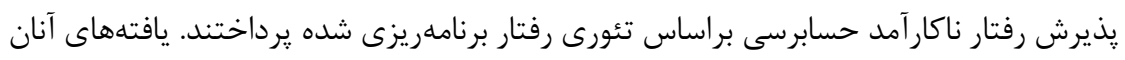

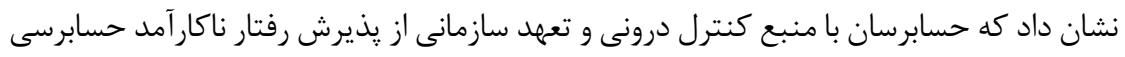

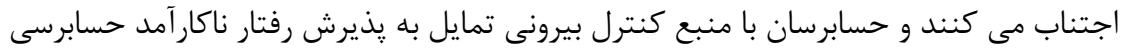
دارند.

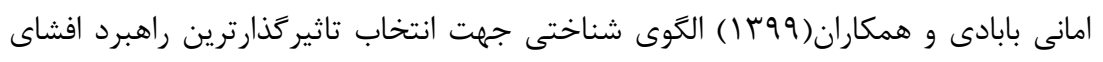

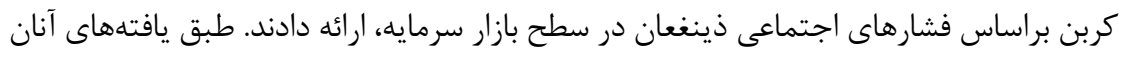

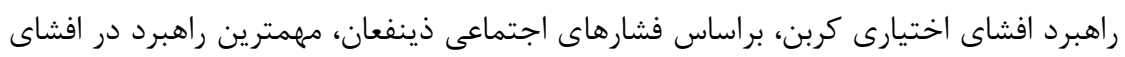

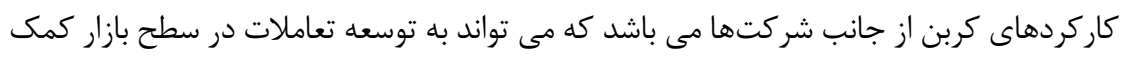

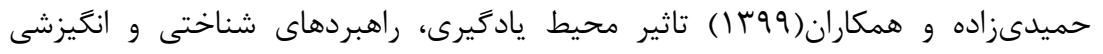

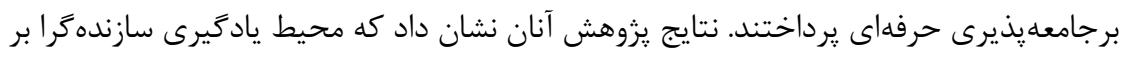

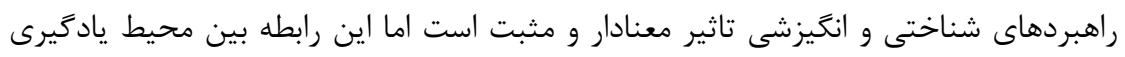

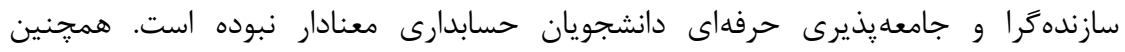

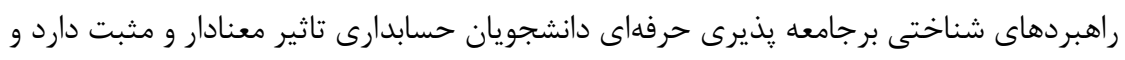

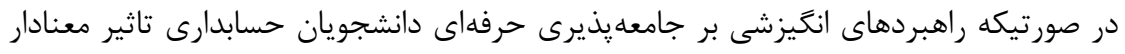


بدين ترتيب، ادبيات موجود درباره عملكردهاى مغز انسان بيانكر اين است كه مغز انسان از

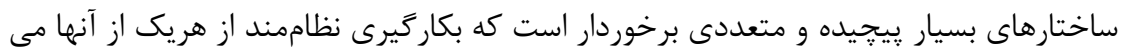

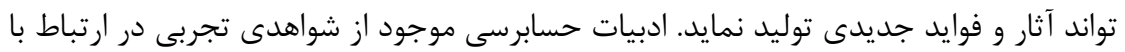

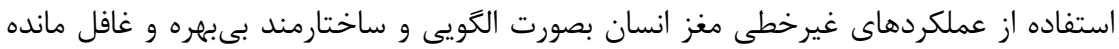

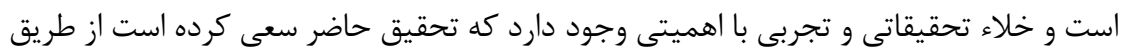

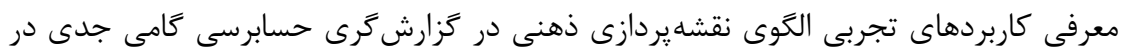
رفع اين خلاء بردارد.

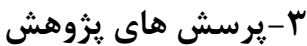

$$
\begin{aligned}
& \text { سوالات اصلى اين بروهش به شرح ذئ ذيل مى بـاشد: }
\end{aligned}
$$

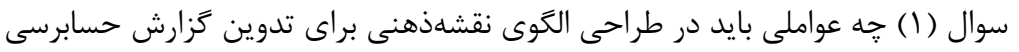

$$
\begin{aligned}
& \text { درنظر گرفته شوند؟ } \\
& \text { سوال(r) الكَوى نقشه ذهنى براى تدوين كَزارش حسابرسى جِكَّنه است؟ }
\end{aligned}
$$

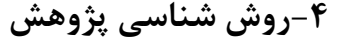

اين يزوهش به لحاظ هدف، از نوع تحقيقات رفتارى اكتشافى است زيرا به بررسى ساختار

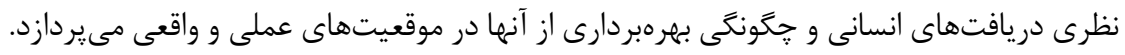

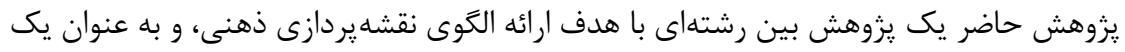

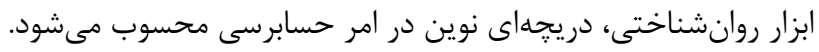

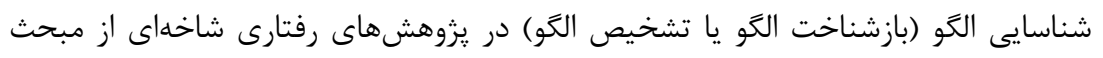

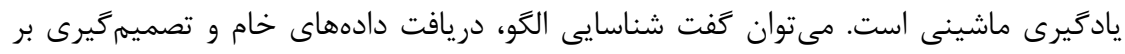

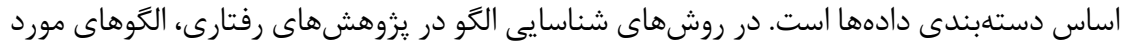

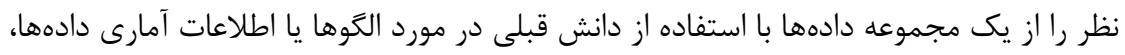

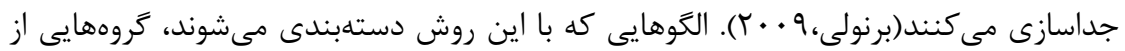

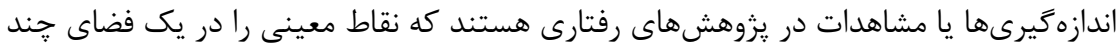

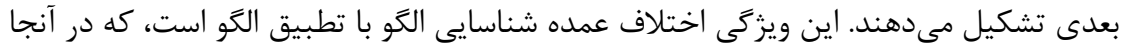

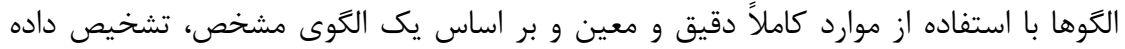

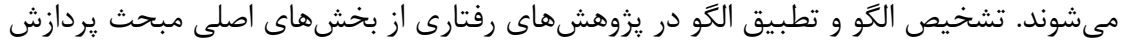

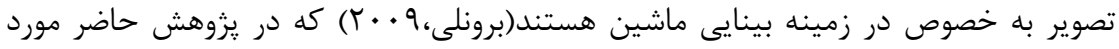

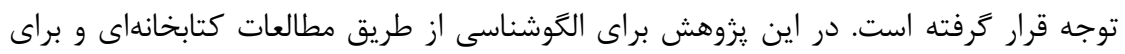


دريافت ديدكاههاى جامعه هدف از يرسشنامه استفاده شدهاست. در تحقيق حاضر در مراحل مختلفى به شرح زير اجرا ترديد: الف) مطالعه مبانى نظرى: در اين مرحله تحقيقات انجام شده در حوزه نقريد نقشهيردازىذهنى به

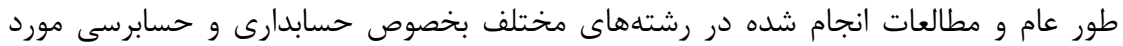

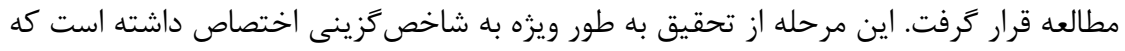

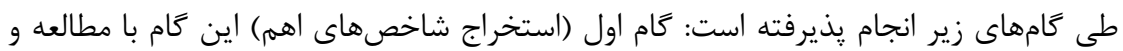
بررسى مبانى نظرى موضوع با استفاده از منابع كتابخانهاى و نيز اخذ مشاوره از له تن از إن حسابرسان

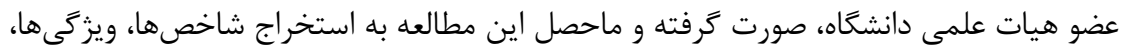

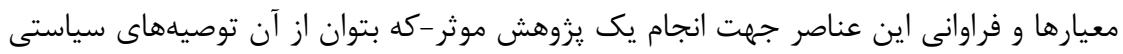

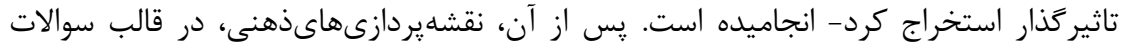

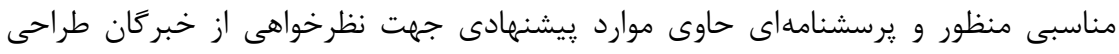
مى تردد. ب) نظرخواهى: در اين مرحله از تحقيق نظر مشاركت كنندكان در مورد عوامل اصلى در

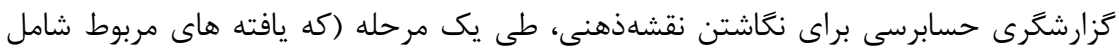

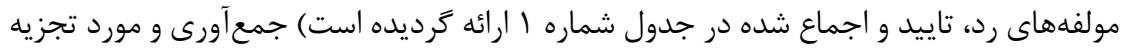

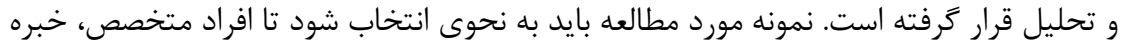

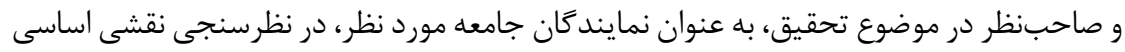

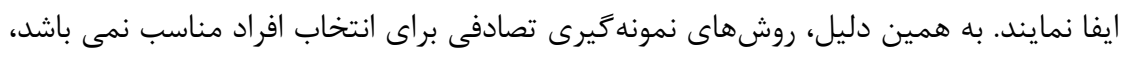
بلكه در اين قبيل يزوهش ها اشخاص صاحبنظر از طريق بررسى دانش، توانمندى و تجربياتى كه دهاي دارند انتخاب مى شوند(رحمانى و همكاران،و 9ب (1).

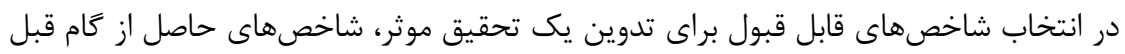

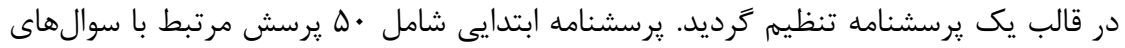

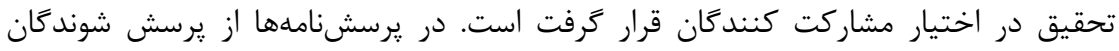

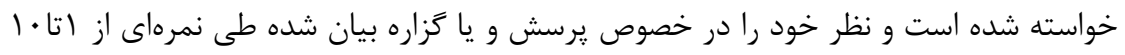
به صورت يك عدد (نه صرفا عدد صحيح بلكه بصورت اعشارى) اعلام نمايند. در تام بعدى (توزيع ندان

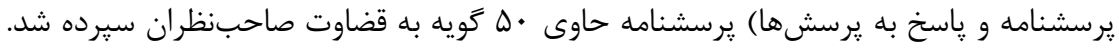

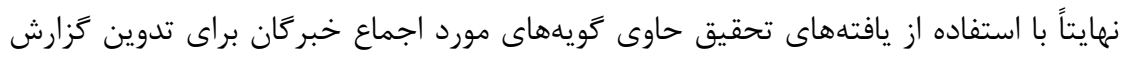

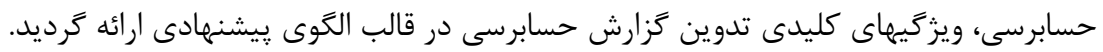

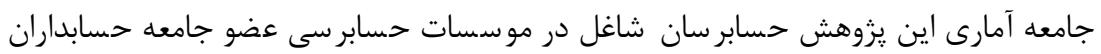

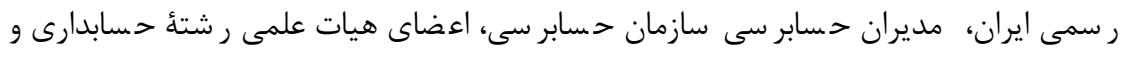


حسابر سى و ساير افراديكه متخصص در حوزه حسابر سى مىباشند، درنظر گرفته شدها ست.

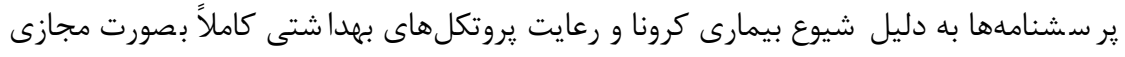

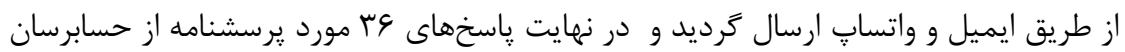

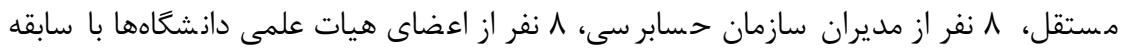

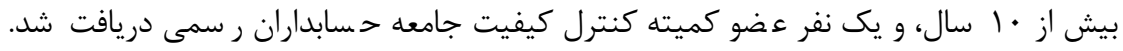

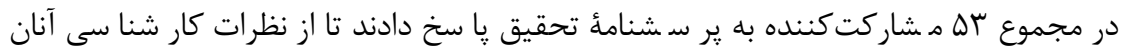
( استفاده كردد.

ج) تدوين طرح كلى مدل: در آخرين مرحله تحقيق، دادهها با استفاده از آزمونهاى آمارى نظير

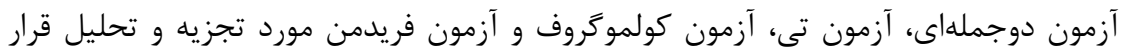

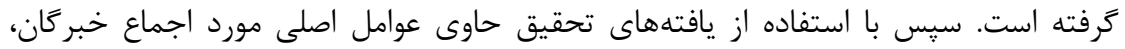

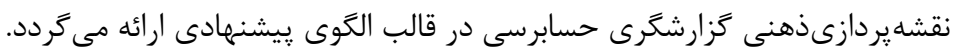

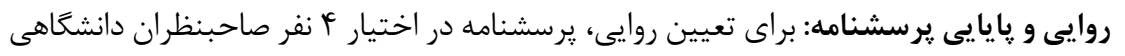

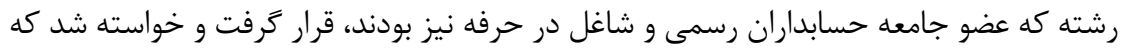

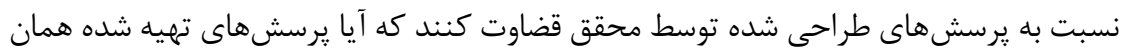

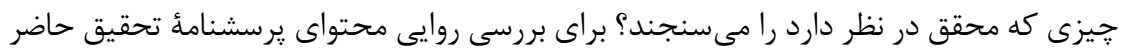

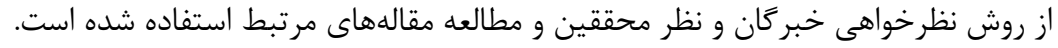

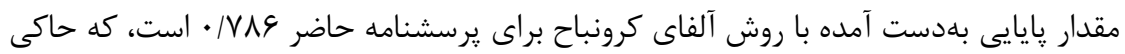

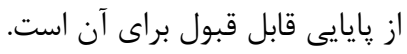

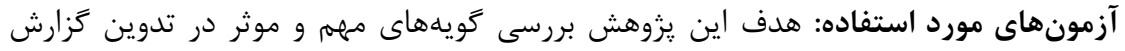

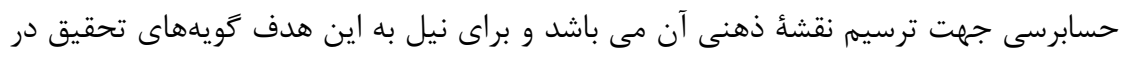

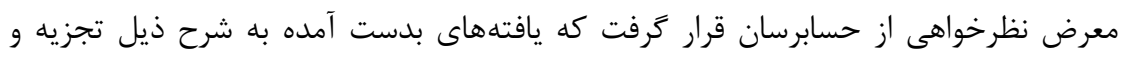

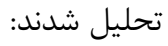

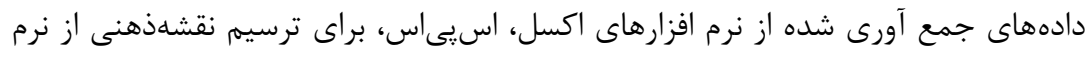

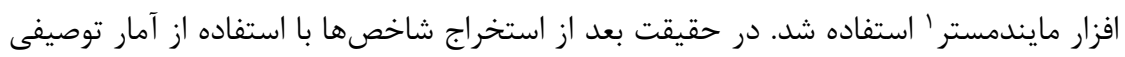

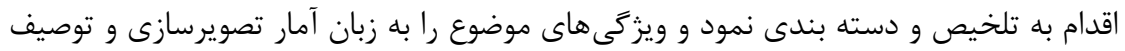

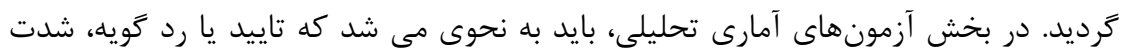

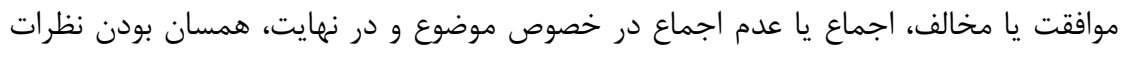

\footnotetext{
1. MindMaster
} 
راجع به موضوعات يا وجود اختلاف نظر معنى دار در بين آنها روشن و معين مى شد. بدين منظور

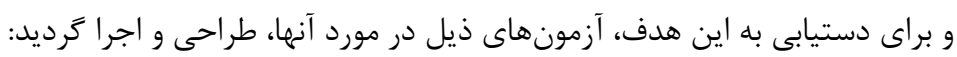

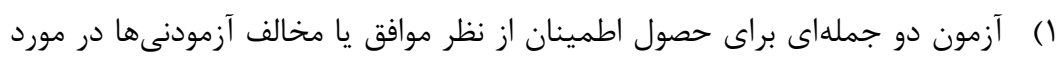

$$
\text { هريك از تويهها }
$$

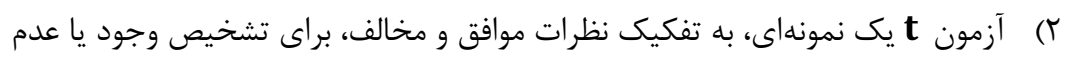

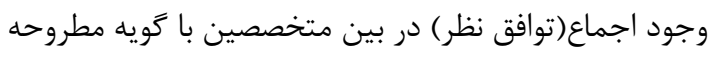

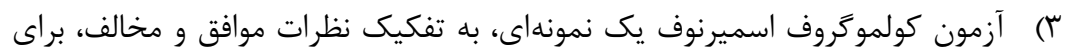
تشخيص وجود يا عدم وجود اجماع (توافق نظر) در بين متخصصين راجع به هر كويه

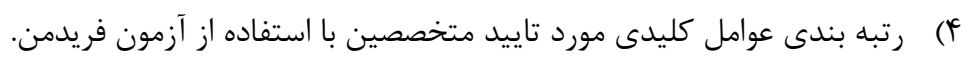

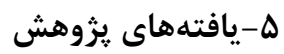

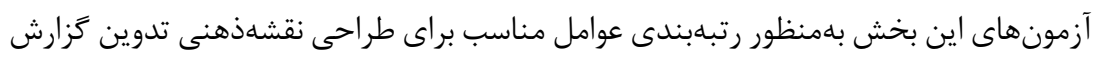

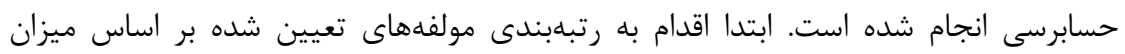

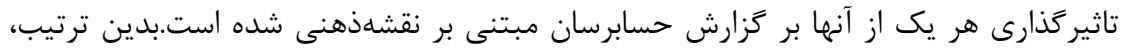

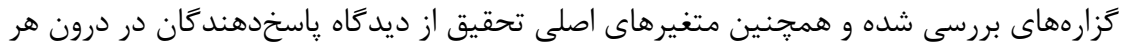

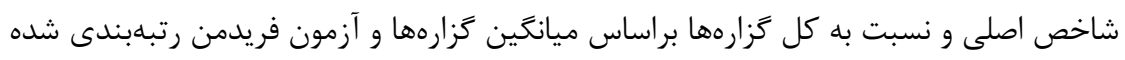

\begin{tabular}{|c|c|c|c|c|c|c|c|}
\hline \multicolumn{8}{|c|}{ جدول (1) رتبه بندى شاخصها از ديدFاه مشاركت كنندكان } \\
\hline ميانكَين & رتبه & زمون & كولموكروف آزمون & 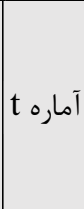 & تا تاييد & دآ آزماره & كويه \\
\hline 9.90 & 1 & 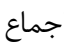 & F.YQF & $\Delta . \Delta 9$ & تاييد & $\Delta . \cdot V$ & ارزيابى ريسك ذاتى \\
\hline 9.9 & $r$ & جماع & r.DSV & $1 . \Lambda$ & تاييد & 4.19 & ارزيابى ريسك كنترل \\
\hline $9.4 \mathrm{TS}$ & $r$ & 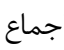 & T.YS & 11.94 & تاييد & G.V. & ارزيابى ريسك عدم كشف \\
\hline $9 . r \vee \Delta$ & f & 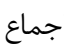 & T.qus & 1.1 & تاييد & 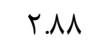 & انحراف از استاندارد حسابدارى \\
\hline 9.490 & $\Delta$ & 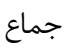 & T.tro & t.f. & تاييد & F.AT & تاييديه داراى مغايرت دريافتى از بانك \\
\hline 9.481 & 4 & جماع & r.Y. & 9.10 & تاييد & $0 . \cdot 4$ & تاييديه داراى مغايرت دريافتى از \\
\hline 9.rTa & $\mathrm{v}$ & جماع & זיז & T.r & تاييد & $v . .9$ & تاييديه دريافت نشده از بانك \\
\hline
\end{tabular}

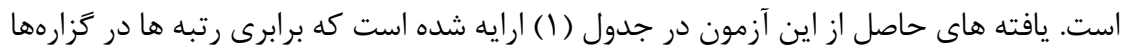
را نشان مى دهد. 
دكترنونهال نهر و همكاران ، ارائه التَوى نقشهيردازى ذهنى براى تدوين تَزارش حسابرسى

\begin{tabular}{|c|c|c|c|c|c|c|c|}
\hline 9.41 & $\wedge$ & 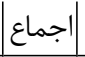 & $\boldsymbol{\varphi} . \Delta \wedge \mathrm{r}$ & $\mid \cdot \cdot 1$ & تاييد & $0.9 \%$ & تاييديه دريافت نشده از اشخاص \\
\hline$\Lambda .9 \Delta \Delta$ & 9 & |جماع & $r . Y \cdot r$ & 1.14 & تاييد & 0.94 & نظر ساير شركاى موسسه \\
\hline$\wedge . \wedge \Delta$ & $1 \cdot$ & 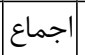 & r.A19 & T.VF & تاييد & 9.9 & سطح اهميت تعيين شده \\
\hline$\Lambda . V T \Delta$ & 11 & |جماع & r.VI & $r . \Delta V$ & تاييد & 4.11 & محدوديت خارج از كنترل واحد تجارى \\
\hline N.rTd & $1 T$ & | - اجماع & F.DFG & r.A & تاييد & G.FT & ارزيابى تداوم فعاليت \\
\hline $1.1 \cdot 1$ & 11 & | - اجماع & r.qVAF & V.. & تاييد & 4.11 & ترديد درشناسايى سود و زيان يروزهها \\
\hline$\Lambda .91$ & 14 & | اجماع| & $r . \wedge \Delta f$ & rI. & تاييد & 4 & احتمال تقلب مديران (كزارشكرى \\
\hline$\vee .9 \vee \Delta$ & 10 & | - اجماع & r.f & $14.9 \Lambda$ & تاييد & f\& & ارزيابىهاى مدير فنى \\
\hline$V .949$ & 19 & | اجماع| & r..$\Delta \Lambda$ & $q \cdot \wedge$ & تاييد & f.if & 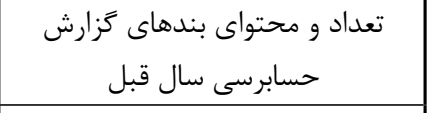 \\
\hline V.AD & IV & | - اجماع & T.ATG| & V.l & تاييد & f.dT & تاييديه مديران \\
\hline$V . \wedge \cdot r$ & 11 & | ل اجماع| & F. $\Delta \wedge \vee$ & IT.Va & تاييد & $\Delta \cdot \wedge$ & 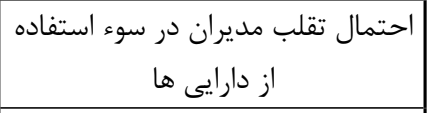 \\
\hline$V .911$ & 19 & |جماع & f.r人f & t.rt & تاييد & $9 . V T^{2}$ & ياسخ هاى دريافتى از حسابرس قبلى \\
\hline V.DT & $r \cdot$ & 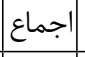 & t.rel & ט.५ & تاييد & r.M & ميزان رعايت مفاد اساسنامه \\
\hline$\wedge . \wedge r \Delta$ & rI & 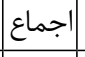 & T.QVY & r). & تاييد & $\Delta . \cdot \Lambda$ & ترديد در نتايج دعواى حقوقى \\
\hline V.rTa & tr & 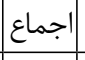 & $\Delta . F \Delta \varphi$ & V.19 & تاييد & $V . \cdot 1$ & ارزيابى كفايت ذخاير \\
\hline$V .1 \cdot \Delta$ & r & | ل اجماع| & $\Lambda . Y I r$ & $1 \cdot . \Delta F$ & تاييد & $9 . V r$ & 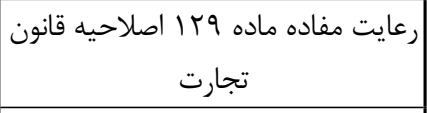 \\
\hline 9.910 & $r F$ & | اجماع| & r.MFI & t.t. & تاييد & $r . \cdot \varphi$ & $\begin{array}{c}\text { رعايت مفاد ماده ץسץ اصلاحيه قانون } \\
\text { تجارت } \\
\end{array}$ \\
\hline G.VT & $r \Delta$ & | - اجماع & t.rVt & 9.10 & تاييد & f.ar & ارزيابى احتمال تقلب كاركنان \\
\hline$G . V \cdot r$ & rq & |جماع| & $r . r \cdot \Delta$ & ᄉ.r & تاييد & r.M & عدم همكارى لازم توسط مديران \\
\hline G.tr & $r v$ & | اجماع| & F.MUF & F.^ & ت ت اييد & $\Delta \cdot . \Lambda$ & اتكا به گَزارش ساير حسابرسان در \\
\hline 9.190 & $r \Lambda$ & | ل اجماع| & F.VFI & r.AN & تاييد & $V . \cdot 1$ & $\begin{array}{c}\text { نوع قرارداد (ارائه گزارش اجمالى يا } \\
\text { كلى) }\end{array}$ \\
\hline 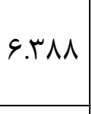 & rq & | اجماع| & f.TDI & r.99 & تاييد & 0.91 & مبهنَام سازى كَارش سال قبل در \\
\hline G.rTr & $r \cdot$ & | ل اجماع| & T.NFT & $1 \cdot . \Delta F$ & تاييد & 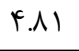 & وضعيت و ويزگى هاى صنعت \\
\hline
\end{tabular}


دو فصلنامه حسابدارى ارزشى و رفتارى، سال ششم، شماره يازدهم، بهار و تابستان ++ع

\begin{tabular}{|c|c|c|c|c|c|c|c|}
\hline 9.14 & r) & 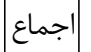 & t.MET & 9.94 & تاييد & $0.9 \mu$ & رعايت مفاد قانون بولشويى \\
\hline 9.11 & rt & 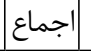 & T.r.4 & $0.8 \wedge$ & تاييد & Q.re & رعايت الزامات قانون محاسبات عمومى \\
\hline 9.99 & س & 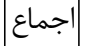 & $r . \Delta \Delta l$ & $r . \Delta F$ & ت ت ت اييد & $r \cdot \cdot 9$ & وضعيت محيطى كارفرما در صنعت \\
\hline $9 \cdot \Delta$ & ry & 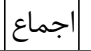 & $f . g 41$ & $0.9 \wedge$ & تاييد & f.人1 & انحراف از بودجه و اثرات آن \\
\hline $9 \cdot \Delta$ & ro & 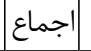 & f.VYl & 4.99 & تاييد & f.or & تاريخ گذارى گَزارش \\
\hline G. ra & re & 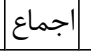 & T.MA૬ & $1 \cdot .91$ & تاييد & 9.19 & افشاى اطلاعات كيفى و توضيحى \\
\hline$G . r \Delta$ & rv & 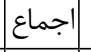 & $r . r \Delta \Lambda$ & V.D9 & تاييد & $\Delta . \cdot r$ & افشاى كمى (رعايت كامل اصل افشاء) \\
\hline$\Delta . \Lambda \cdot \Delta$ & rی & 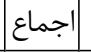 & $f . \omega \cdot r$ & r.ro & تاييد & $9 . \cdot r$ & نظارت بر انبارگردانى و شمارش كالا \\
\hline D.VAT & rq & 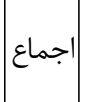 & $r .9 \Delta \Delta$ & Q.FI & تاييد & $1 . r 1$ & حسابرسى شدن صاحبكار براى اولين \\
\hline- & $r \cdot$ & - & - & - & مفاقد & 1.01 & ضعف در كنترل هاى داخلى \\
\hline- & 41 & - & - & - & تفاوت & 1.99 & رعايت ساير الزامات مقرر در اصلاحيه \\
\hline- & Ft & | اجماع| & IT.DF & 1.1 .1 & رد & $V . \cdot 1-$ & مشاهده عينى، اموال، تجهيزات و \\
\hline- & F & 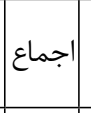 & F.ఎG & Q.rs & رد & $0.91-$ & 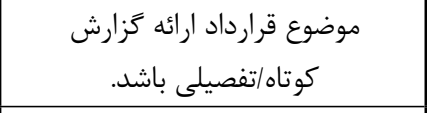 \\
\hline- & FF & |جماع & t.rol & V.19 & رد & G.Vr- & تعامل با كميته حسابرسى \\
\hline- & $r d$ & 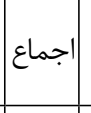 & و 9 & $1 T .9 \mathrm{~V}$ & رد & F. $\Delta r_{-}$ & توجه به حق الزحمه توسط موسسه \\
\hline- & is & 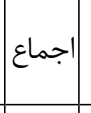 & $r .11$ & $\mid r . \Delta \Lambda$ & ر & $\Delta . \varphi^{\mu}-$ & توجه به توسعه موسسه حسابرسى \\
\hline- & iv & 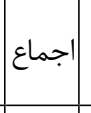 & $F .1 \mathrm{~V}$ & r.r.t & رد & $r . \varphi_{-}$ & توجه به استراتتى حفظ مشترى توسط \\
\hline- & $i \wedge$ & |اجماع| & r.sVV & 4.90 & رد & F.AI- & توجه به استراترى حذف مشترى \\
\hline- & $4 q$ & |جماع| & r.rGl & Q. 1 & رد & $9.9_{-}$ & تصميم كيرى در مورد فسخ يا انصراف \\
\hline & $\Delta \cdot$ & |جماع| & r.r人s & r.DG & رد & $\Delta . \mathscr{T}-$ & تر اثر و اهميت رويدادهاى بعد از تاريخ \\
\hline
\end{tabular}




\section{" جََونكَى استتخراج و ترسيم الكوى نقشه يردازى ذهنى تدوين كزارش حسابرسى}

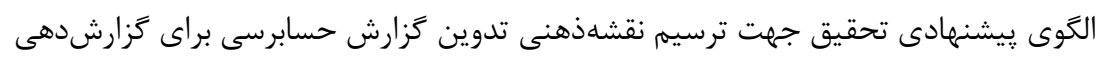

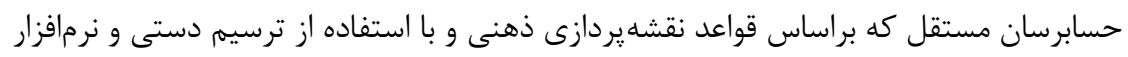

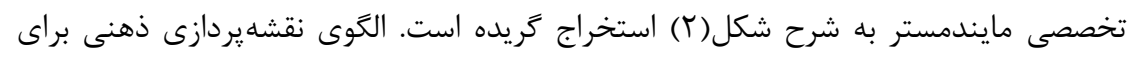

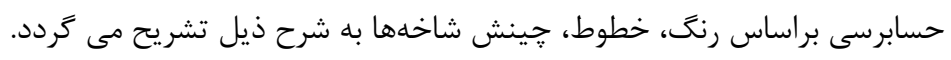

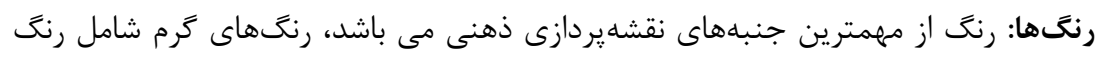

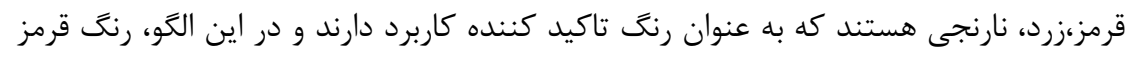

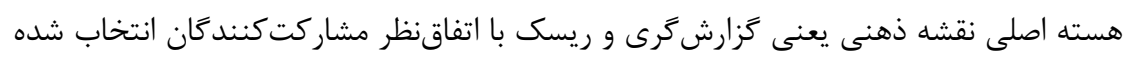

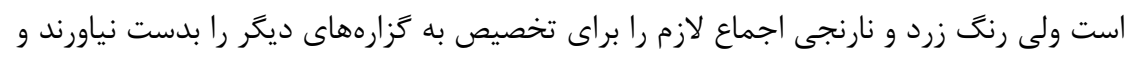

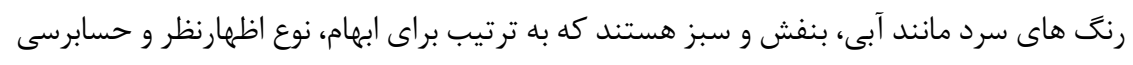

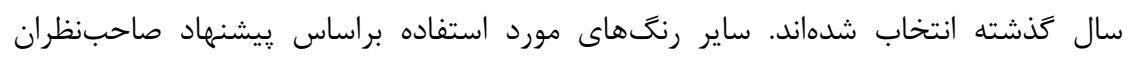

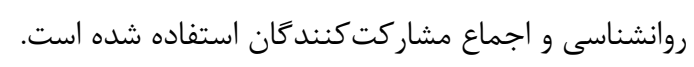

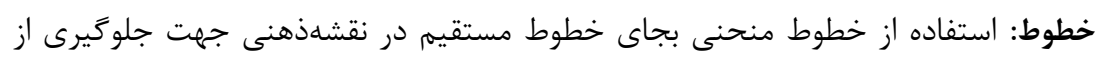

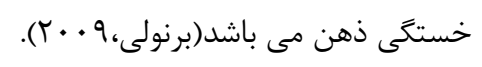

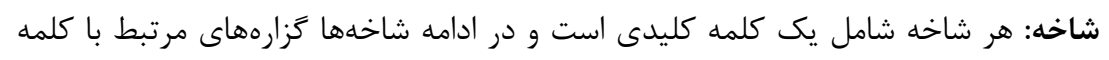

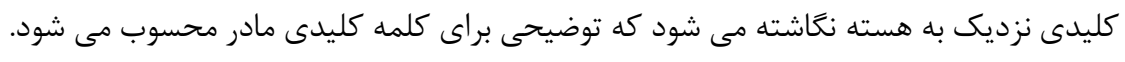

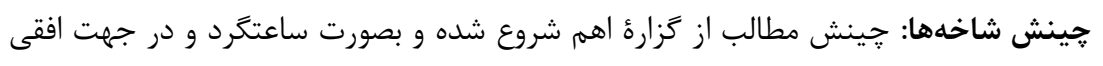

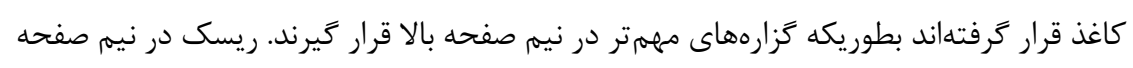

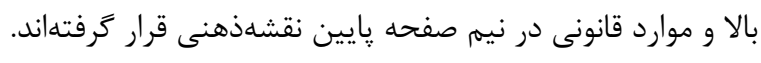

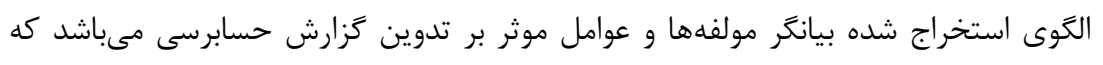

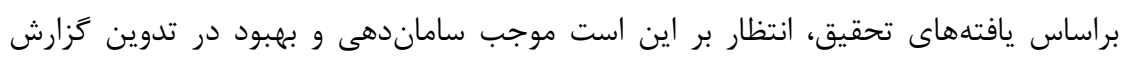

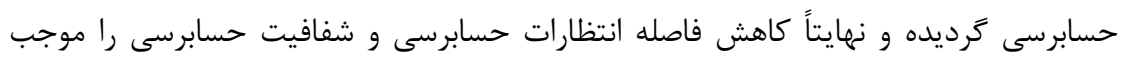

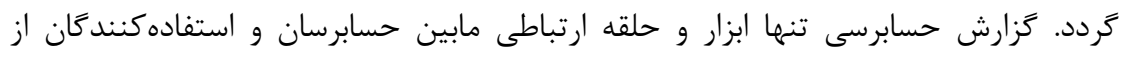

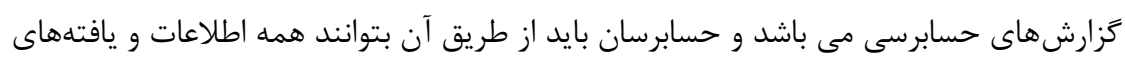

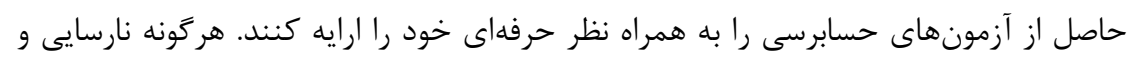

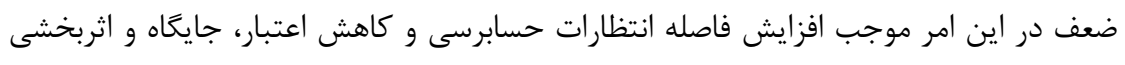

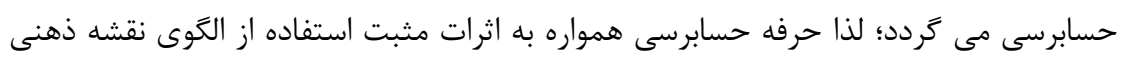

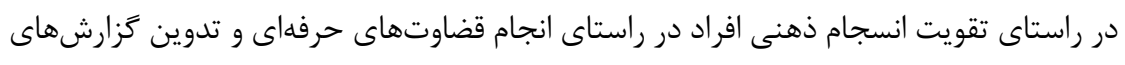

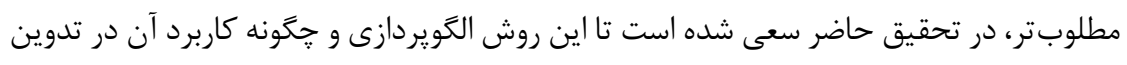

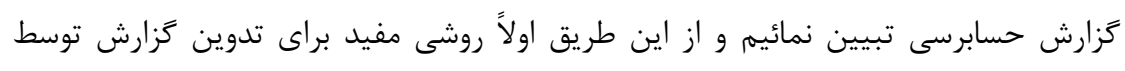


حسابرسان فراهم نمائيه؛ دوماً باب يزوهشى و نظرى جديدى براى يزوهش حران و تدوين كنندكان استانداردهاى حسابرسى بخشائيم. اعتبارسنجى الكو

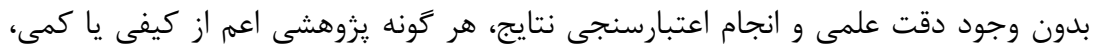

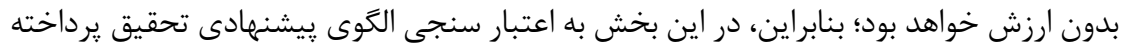

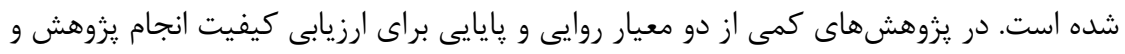

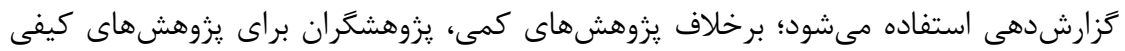

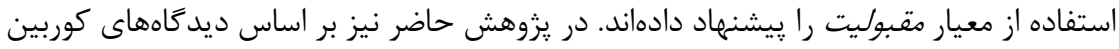

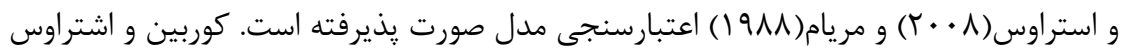

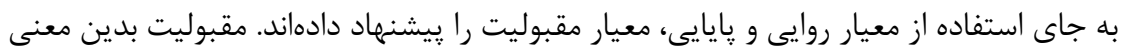

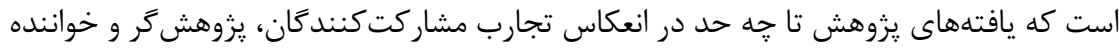

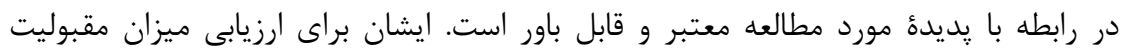

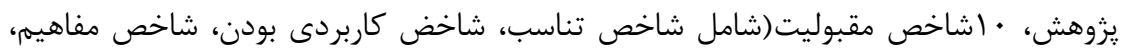

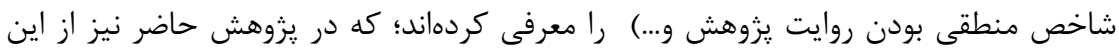

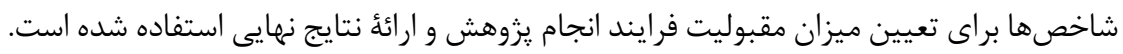

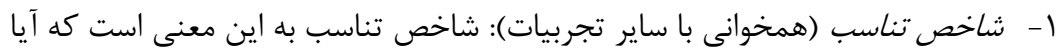

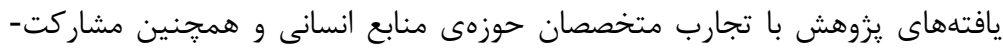

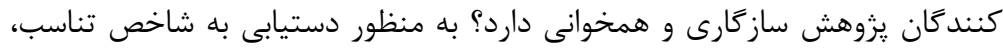

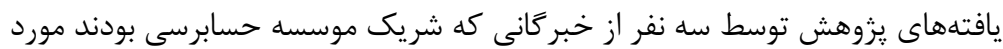

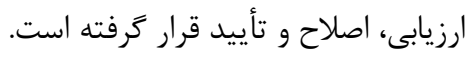

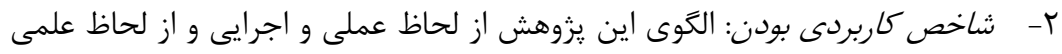

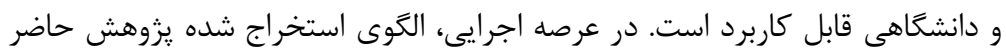

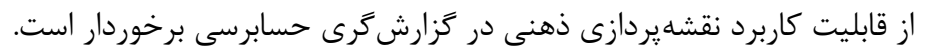

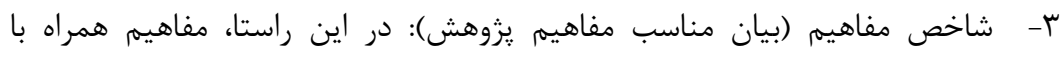

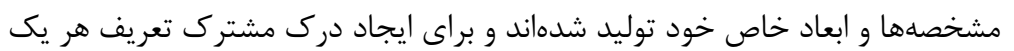

$$
\text { از مفاهيم اشاره شده است. }
$$

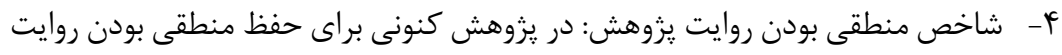

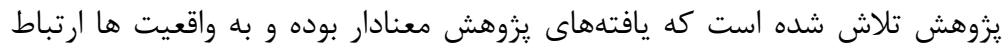

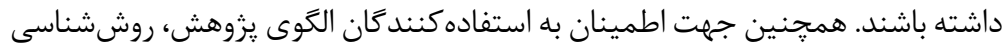
و شيوه گردآروى و تحليل دادها به اندازمى مناسب توضيح و بيان شده است. 


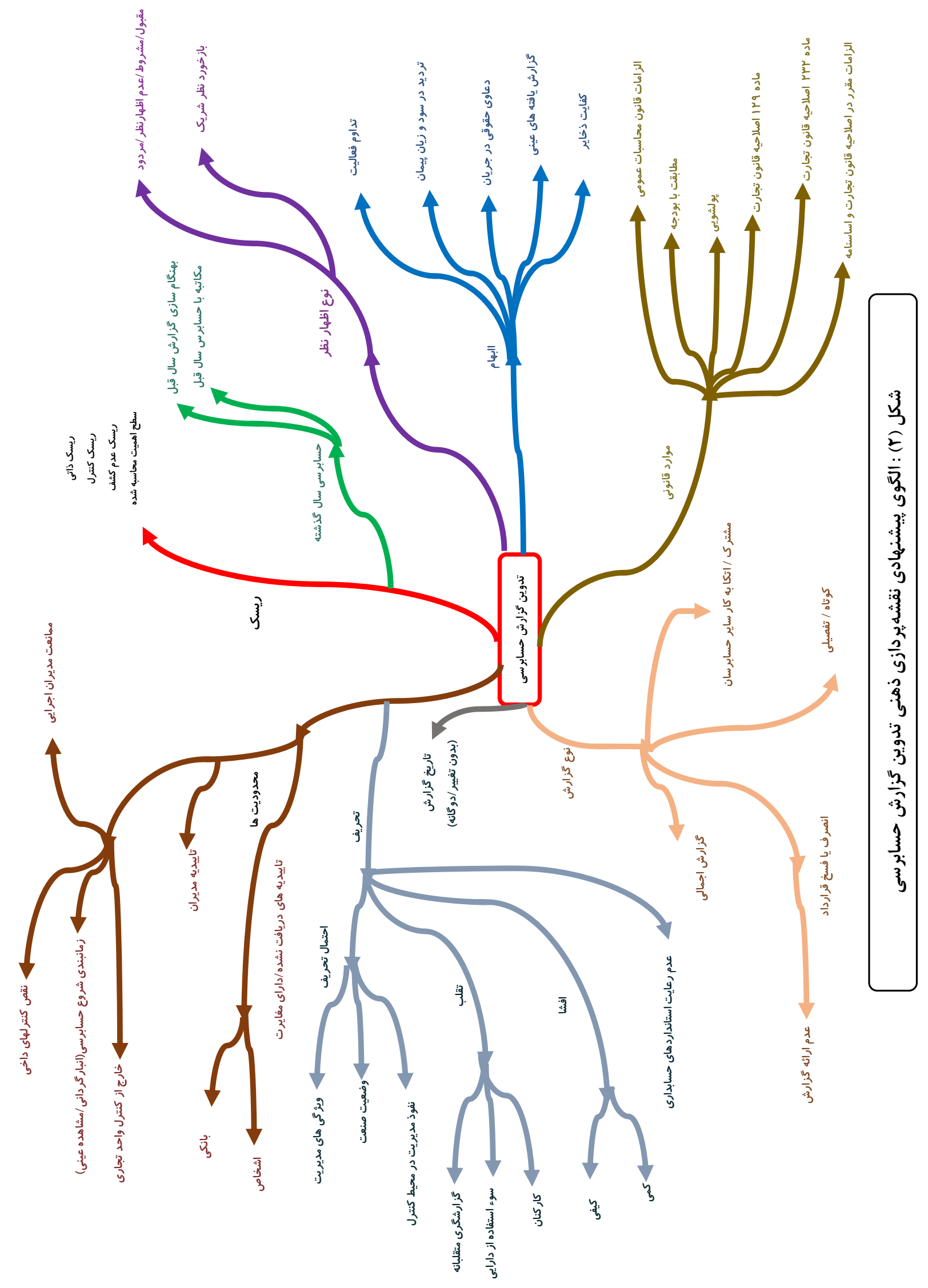


ه- شاخص عمق (بيان تفصيلى روايت يزوهش): در راستاى تعميق يزوهش كنونى، الكوى

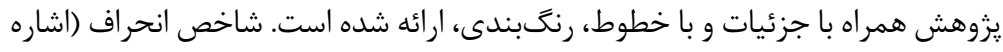

به استثنائات و موارد متناقض با يافتهها):

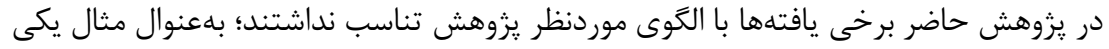

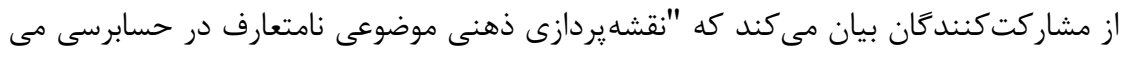

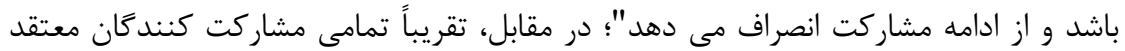

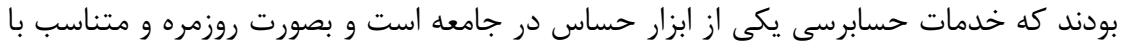

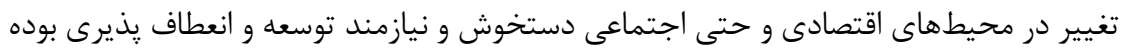

9- شاخص بداعت (ارائه مفاهيم جديد): در يزوهش حاضر نوآورى و ابزار جديد با قابليت

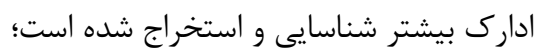

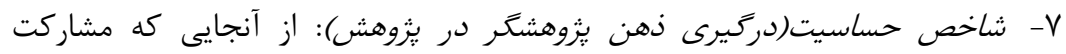

كنندكان يزوهش حاضر شاغل در موسسات حسابرسى مى براشند داراى تجربه كار

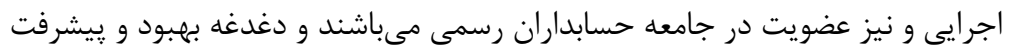

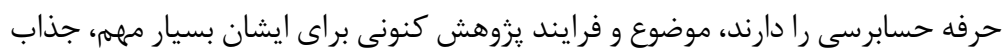

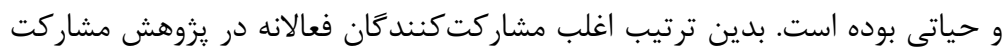

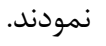

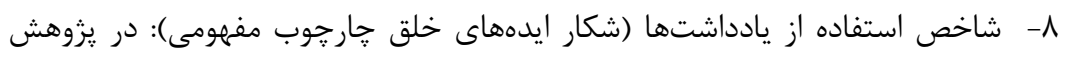

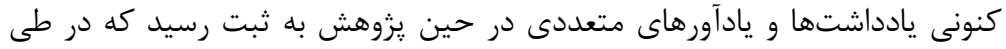

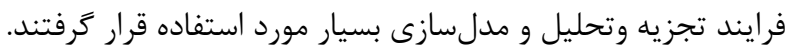

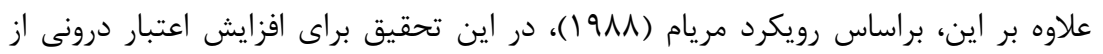

روشهاى كثرت

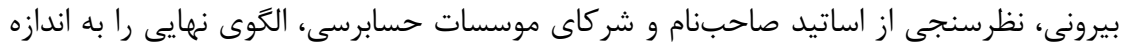

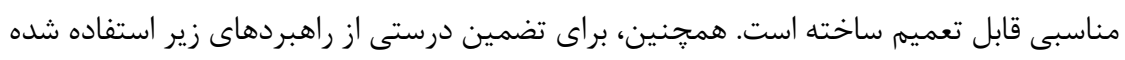

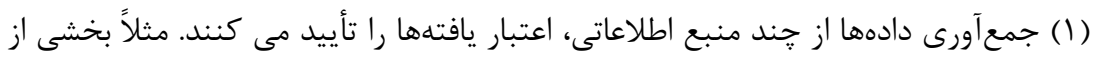
مشاركت كنندكان اساتيد دانشخاهى بودند، (T) با روش مقايسه دائمى در تحليل دادهها، اعتبار افزايش مىيابد. در اين روش، مقايسه

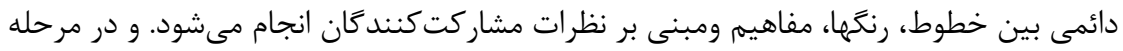


حميدى زاده و همكاران، تاثير محيط يادَّيرى، راهبردهاى شناختى و انَّيزشى بر جامعه يذيرى حرفه ایى...

دوم، ضمن سوال در مورد روابط بين اجزاء در مورد ماهيت متغيرها و اعتبار مدل مفهومى اوليه بحث شد.

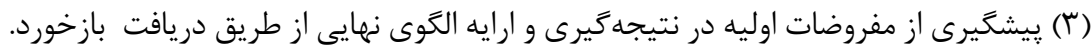

\section{9-بحث و نتيجه}

الكوى نقشهذهنى ابزارى جهت انسجامبخشى به عملكردهاى ذهنى افراد و كمك به ايشان در

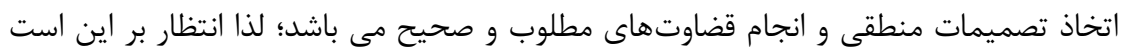

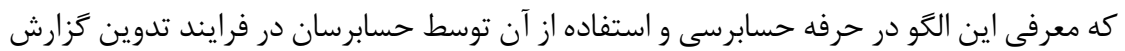

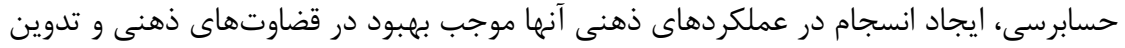

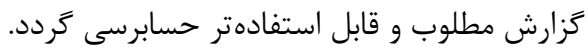

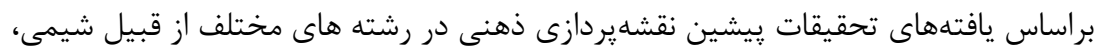

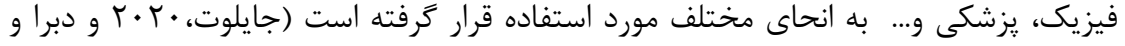

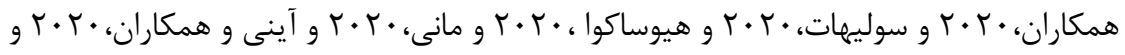

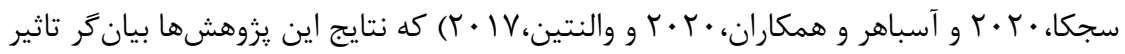

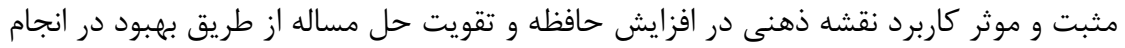
عملكردهاى ذهنى ايشان بودهاست.

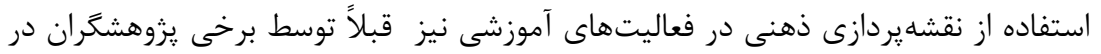

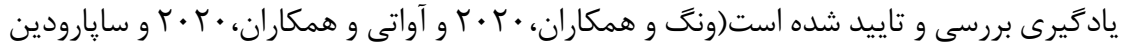

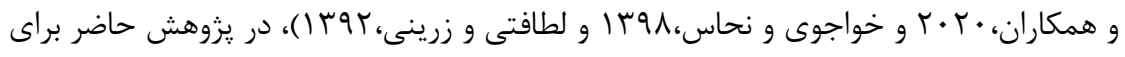

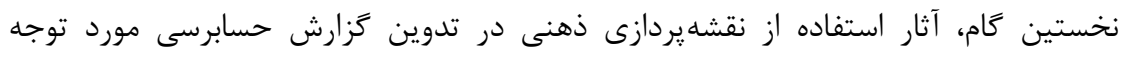

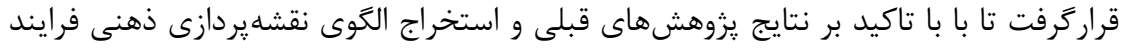

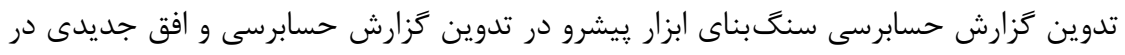

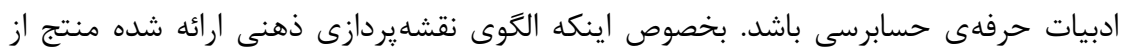

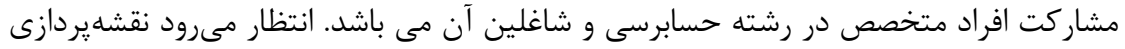

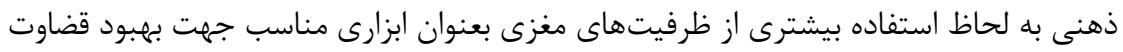

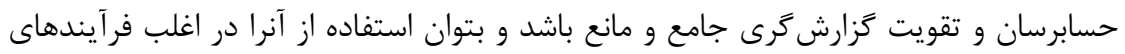

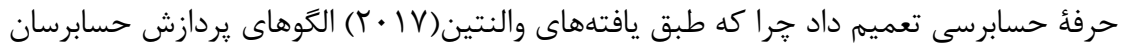

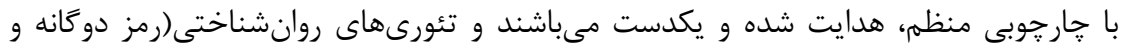

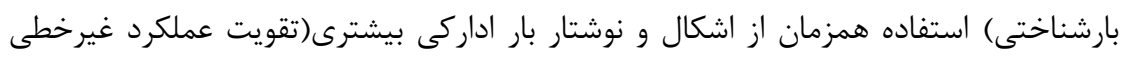


مغز) دارد. با توجه به اينكه الكوىهاى استخراجى در يزوهشهاى يُشين و محتواى آنها از قبيل

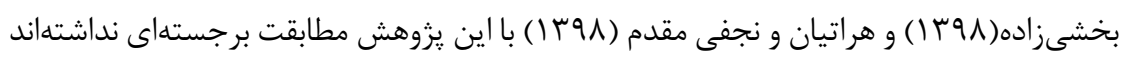

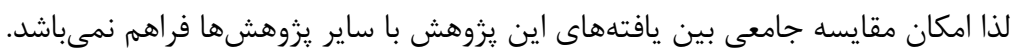

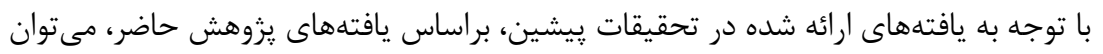

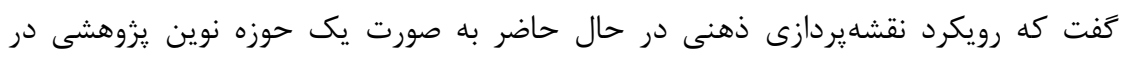

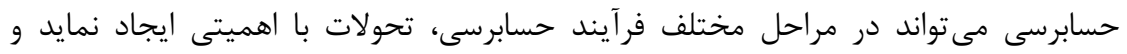

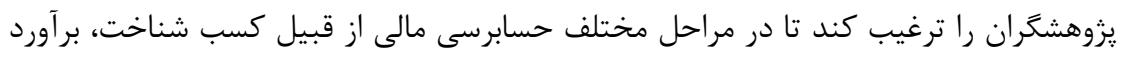

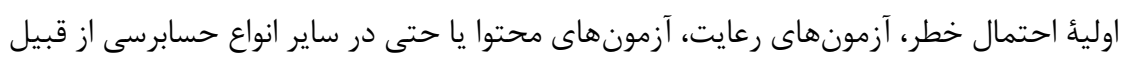

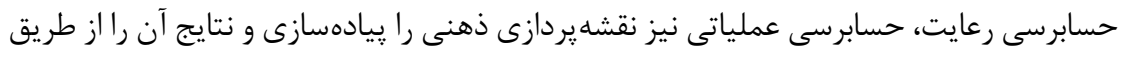

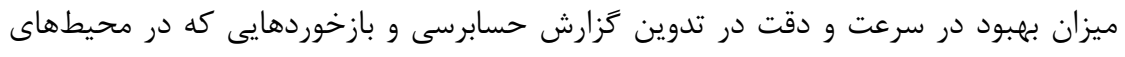

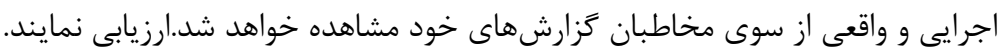

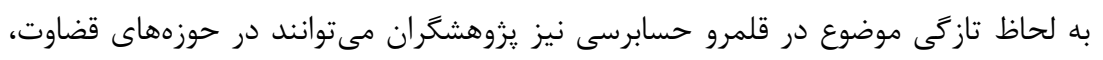

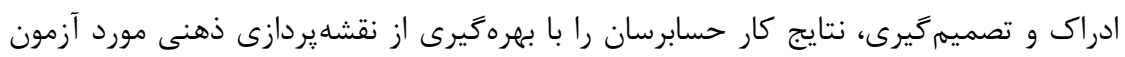
قرار دهند.

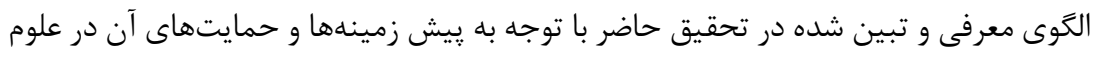

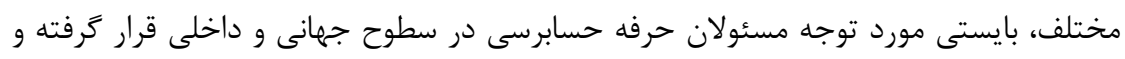

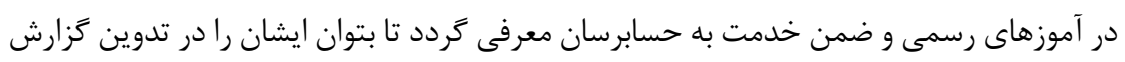

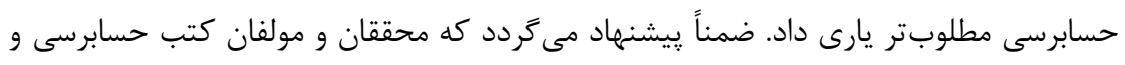

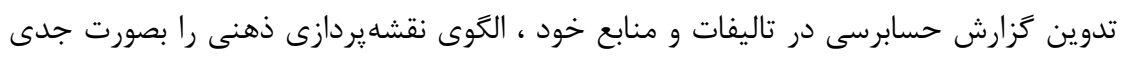
مورد استفاده و توجه قرار دهند. تورسي

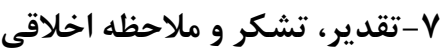

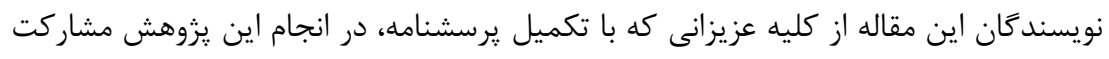
نموده اند، كمال تشكر و قدردانى را دارند. 


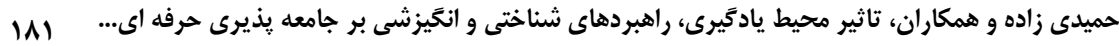

\begin{tabular}{|c|c|c|}
\hline \multicolumn{3}{|c|}{ 1- ييوست ها } \\
\hline | امتياز ا(كمترين) تا امتياز & به نظر شما هر يك از موارد ذيل در تنظيم حزارش حسرى & . \\
\hline & |رزيابى ريسك ذاتى & 1 \\
\hline & |رزيابى ريسك كنترل & $r$ \\
\hline & |رزيابى ريسك عدم كشف & r \\
\hline & |نحراف از استاندارد حسابدارى & f \\
\hline & |تاريخخذارى گزارش & $\Delta$ \\
\hline & نظر ساير شركاى موسسه & 4 \\
\hline & |سطح اهميت تعيين شده & v \\
\hline & |محدوديت خارج از كنترل واحد تجارى & $\Lambda$ \\
\hline & |رزيابى تداوم فعاليت & 9 \\
\hline & |ترديد در شناسايى سود و زيان يروزهها & 1. \\
\hline & |حتمال تقلب مديران (خزارشخُى متقلبانه) & 11 \\
\hline & |رزيابىهاى مدير فنى & it \\
\hline & |تعداد و محتواى بندهاى كزارش حسابرسى سال قبل & Ir \\
\hline & |تاييديه مديران & if \\
\hline & |حتمال تقلب مديران در سوء استفاده از دارايى ها & 10 \\
\hline & |ياسخ هاى دريافتى از حسابرس قبلى & 19 \\
\hline & |ميزان رعايت مفاد اساسنامه & IV \\
\hline & |ترديد در نتايج دعواى حقوقى & 11 \\
\hline & |رزيابى كفايت ذخاير & 19 \\
\hline & |رعايت مفاده ماده 9 | I اصلاحيه قانون تجارت & $r$. \\
\hline & |رعايت مفاد ماده Y T اصلاحيه قانون تجارت & rI \\
\hline & |رزيابى احتمال تقلب كاركنان & tr \\
\hline & عدم همكارى لازم توسط مديران اجرايى & سז \\
\hline & |نظارت بر انبارگردانى و شمارش كالا & TF \\
\hline & |تكا به گزارش ساير حسابرسان در موارد مقتضى & ra \\
\hline & |نوع قرارداد ( ارائه كزارش اجمالى يا كلى) & rq \\
\hline
\end{tabular}


دو فصلنامه حسابدارى ارزشى و رفتارى، سال ششم، شماره يازدهم، بهار و تابستان +.+عا

\begin{tabular}{|c|c|c|}
\hline & |بهنَام سازى گزارش سال قبل در موارد مقتضى & tr \\
\hline & وضعيت و ويزگى هاى صنعت & r人 \\
\hline & |تصميمم گيرى در مورد فسخ يا انصراف قرارداد & rq \\
\hline & |رعايت مفاد قانون يولشويى & r. \\
\hline & |رعايت الزامات قانون محاسبات عمومى & ו \\
\hline & |وضعيت محيطى كارفرما در صنعت & re \\
\hline & |نحراف از بودجه و اثرات آن & س \\
\hline & |فشاى اطلاعات كيفى و توضيحى & me \\
\hline & |فشاى كمى (رعايت كامل اصل افشاء) & ra \\
\hline & |تاييديه دريافت نشده از بانك & re \\
\hline & |تاييديه دريافت نشده از اشخاص & rV \\
\hline & |تاييديه داراى مغايرت دريافتى از بانك & ऍی \\
\hline & |تاييديه داراى مغايرت دريافتى از اشخاص & rq \\
\hline & ضعف در كنترل هاى داخلى & $\varphi$. \\
\hline & |رعايت ساير الزامات مقرر در اصلاحيه قانون تجارت & (i) \\
\hline & مشاهده عينى، اموال، تجهيزات و ماشين آلات & fr \\
\hline & |موضوع قرارداد ارائه گَزارش كوتاه/تفصيلى باشد. & Fr \\
\hline & توجه به استراتزى حفظ مشترى توسط موسسه حسابرسى & fF \\
\hline & توجه به استراترى حذف مشترى توسط موسسه حسابرسى & $i \Delta$ \\
\hline & توجه به توسعه موسسه حسابرسى توسط شركا & iq \\
\hline & توجه به حق الزحمه توسط موسسه حسابرسى & FV \\
\hline & تعامل با كميته حسابرسى & $\uparrow \wedge$ \\
\hline & |حسابرسى شدن صاحبكار براى اولين بار & $4 q$ \\
\hline & |اثر و اهميت رويدادهاى بعد از تاريخ ترازنامه & $\Delta \cdot$ \\
\hline
\end{tabular}

\section{فهرست منابع}

ابراهيمى، فهيمه و نجفى، زهر|(99 (1)، نقش حسابدارى ذهنى در رفتار مالياتى خويش فرمايان (مورد مطالعه: موديان حقيقى استان فارس)، دو فصلنامه حسابدارى ارزشى و رفتارى،

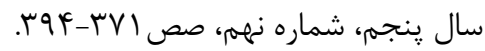

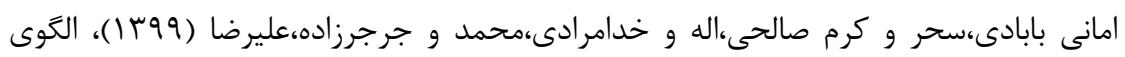
شناختى انتخاب تاثيرگذارترين راهبرد افشاى كربن براساس فشارهاى إدرى اجتماعى 


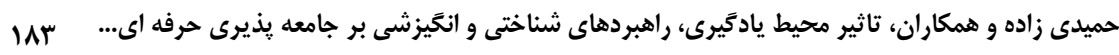

ذينفعان: رويكردهاى تحليلى مجموعه راف، دو فصلنامه حسابدارى ارزشى و رفتارى،

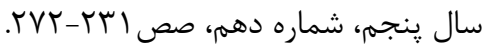

اسدى، مرتضى؛ نعمتى، محمد(بو ب ()، قضاوت حرفهاى در حسابرسى، فصلنامه حسابدار رسمى،

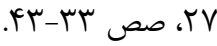

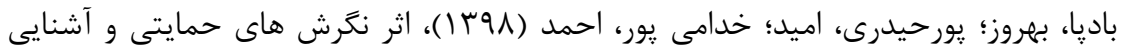

حسابرس با صاحبكار بر قضاوت اوليه حسابرس و استراترى جستجوى شواهد،

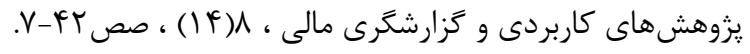

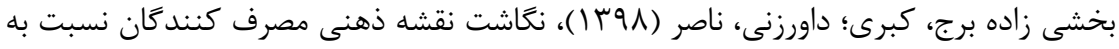

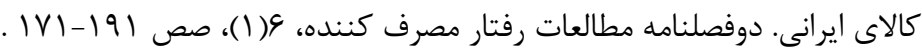

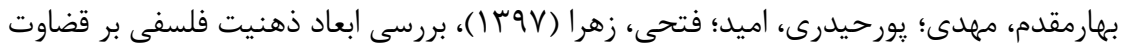

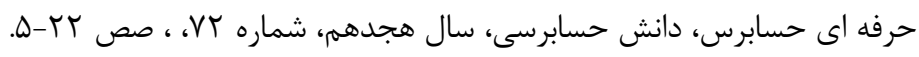

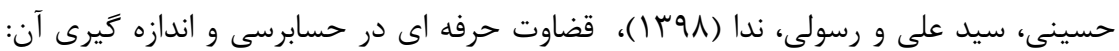

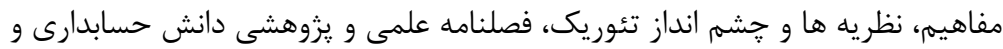

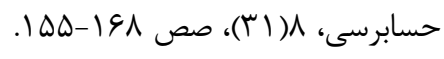

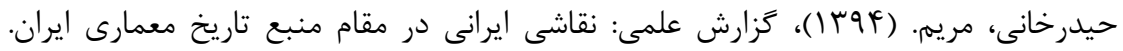

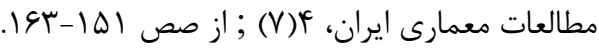

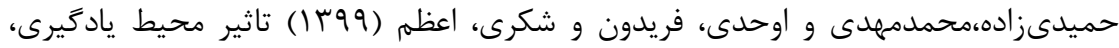

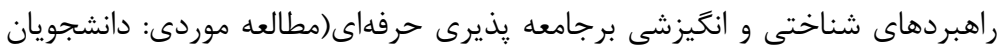
دورههاى تحصيلات تكميلى رشته حسابدارى دانشگاه ازاد اسلامى)، دو فصلنامه

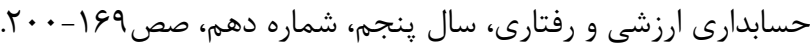

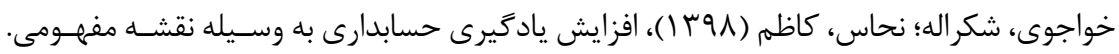

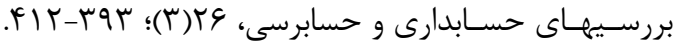

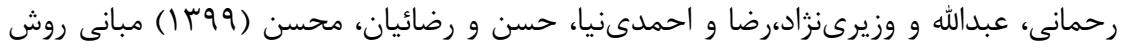

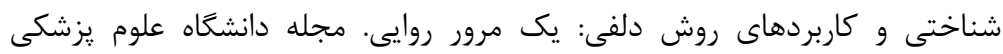

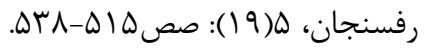

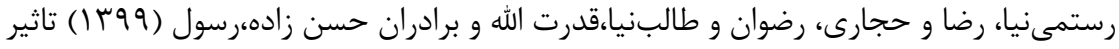

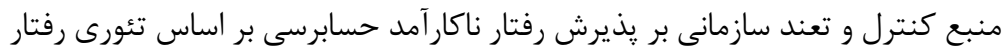

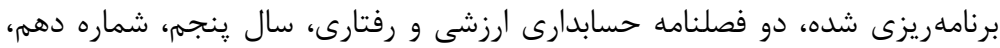

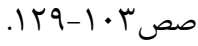




$$
\begin{aligned}
& \text { دو فصلنامه حسابدارى ارزشى و رفتارى، سال ششم، شماره يازدهم، بهار و تابستان +•|ع } \\
& \text { سازمان حسابرسى،اصول حسابرسى يك(99 ( ) نشريه NV سازمان حسابرسى، انتشارات سازمان }
\end{aligned}
$$

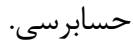

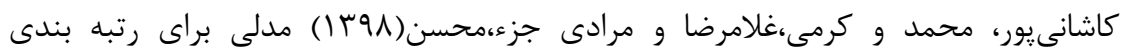

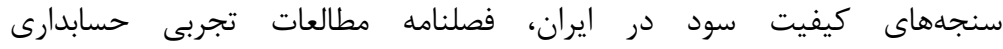

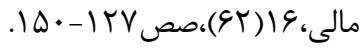

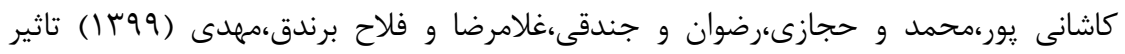

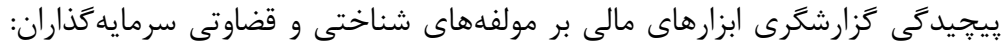

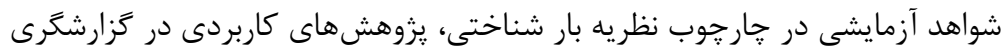

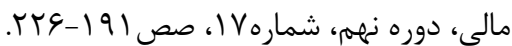

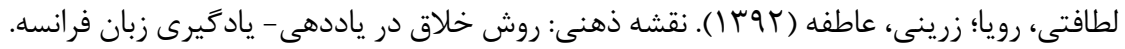

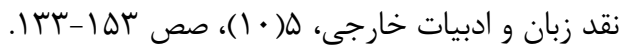

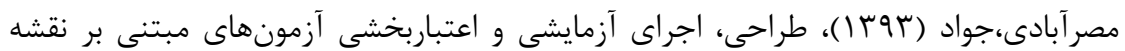

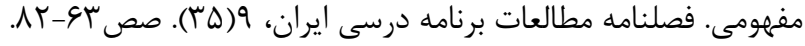

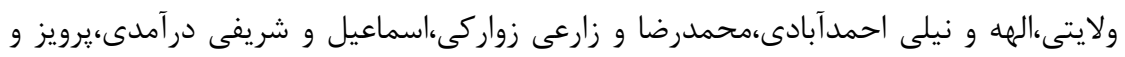

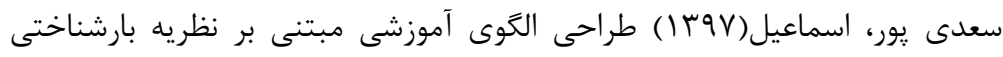

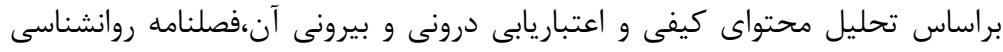

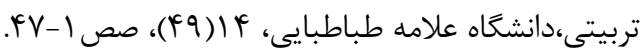

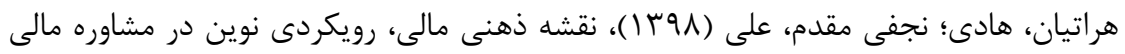

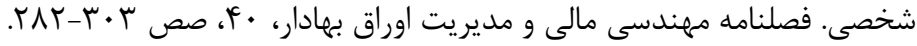

Aini, Q and E.P. Harahap, and F. Faradilla. 2020, the Effects of Sales Reports Business Intelligence on Employee Performance, ATM, 4(1): 83-91.

Al-Jarf. Reima ,2021. Teaching Reading to EFL Freshman Students with Mind Mapping Software, journal for research school and professionals of English learning,5(24), pp 1-12.

Asbahr.K and K. Ruhnke .2019. Real effects of reporting key audit matters on auditors' judgment and choice of action, International Journal of Auditing,23(2): 165-180.

Awati J. S and S.S. Desai, S. Tope. 2020. Mind Mapping: An Effective Teaching Learning Evaluation Tool in Engineering Education, journal of engineering education transformations, 33(1): 78-83.

Brunelli.R, 2009. Template Matching Techniques in Computer Vision: Theory and Practice, Wiley. 


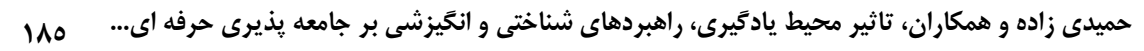

Canadian Institute of Chartered Accountants, 1995. Professional Judgment and the Auditor, CICA Research Study Group, Toronto, CICA.

Cejka.P, and H. Mohelska. 2020. National Culture Influence on Organisational Trauma: A Conceptual Framework Review, Information Resources Management Association (USA).

Corbin, J. \& A. Strauss, 2008. Basics of Techniques and Procedures for Developing Grounded Theory (3rd Ed.). Thousand Oaks, CA: Sage Qualitative Research.

Curry, A. 2020 Management Accounting Above and Under Ground, doctoral thesis, Printed by Luleå University of Technology, Graphic Production.

Guilford, J.P,1967. The nature of human intelligence. The Journal of Creative Behavior, 1(1): 3-14.

Deborah.R. I, and A. smart and R.N. White, and M. Mitchell, and T. Gebru, and B. Hutchinson, and J. Smith-Loud, and D. Theron, and P. Barnes, 2020, Closing the AI Accountability Gap: Defining an End-to-End Framework for Internal Algorithmic Auditing, (Fariness, Accountability and Transparency) conference: $33-44$.

Gossack-Keenan.K, and Wit.K, and Gardiner, E, M. Turcotte, and T. Chan, 2020. Showing Your Thinking: Using Mind Maps to Understand the Gaps Between Experienced Emergency Physicians and Their Students, Journal of Society for Academic Emergency Medicine, 4(1): 54-63.

Husáková.M and B. Vladimír. 2020, Formal Ontologies in Information Systems Development: A Systematic Review, Information, 11(66) 1-18.

Hosseini, S. H. 2021 The Effect of Baseline Performance and Age on Cognitive Training Improvements in Older Adults: A Qualitative Review jpad-journal of prevention of alzheimers disease:100-109.

Jaillot.V, and M. Istasse, and S. Servigne, and G. Gesquière, and M. Rautenberg, and I. Lefort 2020, Describing, comparing and analysing digital urban heritage tools: A methodology designed with a multidisciplinary approach, Journal Digital Applications in Archaeology and Cultural Heritage, 17: 1-30. 
Mališ, S. S and L. Žager and Mateja. 2021. The Future of Audit in Light of Technological Changes: Opportunities and Threats, Fostering Innovation and Competitiveness with FinTech, RegTech, and SupTech: 228-249.

Merriam, S.B. 1988. Case Study Research in Education: A Qualitative Approach. Jossey-Bass, San Francis-co, Journal of the American Geriatrics Society, 36(10): 962-962.

Lincoln, Y. S., \& Guba, E. G. 1985. Naturalistic inquiry. Thousand Oaks, CA: Sage

Saparuddin.S, and A. Nasirwan. 2020, Improving Quality of Learning with Syariah Accounting Mind Mapping Method in Accounting Program at Universitas Negeri Medan, Ekonomi, Keuangan, Investasi dan Syariah (ekuitas), 1(2): 120-125.

Sarbadhikari.SN and K Chakrabarty .2001. Chaos in the brain: a short review alluding to epilepsy, depression, exercise and lateralization, Medical engineering \& physics 23 (7): 447-457.

Solihat, A 2020, Mind Map Research of 5 Years: Financial Modeling and Pro Forma Analysis, Business Innovation \& Entrepreneurship Journal, e-ISSN: 2684-8945, 2(1): 1-8.

Valentim, C and E. Cornachione and A. Rocha and F. Rocha. 2017, Cognitive brain mapping of auditors and accountants in going concern judgments, Revista Contabilidade \& Finanças, 28 (73): 132-147.

Wang.M and B. Cong and Z. Zhao and Z. Su and Y. Tian.2020. Spherical NiCo2O4/CuS composites for supercapacitor electrodes, Materials Letters, 264: 1-5. 